ISSN 0854-9818

\title{
Laju dan Penyebab Deforestasi di Indonesia: Penelaahan Kerancuan dan Penyelesaiannya
}

William D. Sunderlin dan Ida Aju Pradnja Resosudarmo

CENTER FOR INTERNATIONAL FORESTRY RESEARCH

office address: Jalan CIFOR, Situ Gede, Sindangbarang, Bogor 16680, Indonesia mailing address: P.O. Box 6596 JKPWB, Jakarta 10065, Indonesia tel.: +62 (251) 622622 fax: +62 (251) 622100

email: cifor@cgnet.com

$W W W:$ http://www.cgiar.org/cifor 


\section{CGIAR}

Consultative Group on International Agricultural Research (CGIAR - Badan Konsultatif Penelitian Pertanian Internasional) adalah asosiasi informal 41 donor dari sektor umum dan swasta yang membiayai jaringan enam belas pusat penelitian pertanian internasional, di mana CIFOR merupakan pusat penelititan yang terbaru. Kelompok ini berdiri pada tahun 1971. Pusat-pusat penelitian CGIAR adalah bagian dari sistem penelitian pertanian global yang berusaha menerapkan kemampuan ilmiah internasional pada penyelesaian masalah-masalah bagi mereka yang kurang beruntung.

\section{CIFOR}

CIFOR didirikan dibawah sistem CGIAR sebagai tanggapan atas kecemasan dunia mengenai dampak sosial, lingkungan dan ekonomi akibat hilangnya hutan dan degradasi hutan. CIFOR bergerak berdasarkan kerjasama yang berbentuk kemitraan dengan lembaga-lembaga dan/atau individu-individu yang memegang posisi kunci di negara-negara berkembang dan negara-negara industri. Sifat dan jangka waktu kemitraan ini ditentukan oleh masalah-masalah khusus penelitian yang ditangani. Agenda penelitiannya akan dipantau terus menerus dan bisa diubah apabila kedua belah pihak melihat kesempatan dan masalah-masalah baru. 


\section{DAFTAR ISI}

Halaman

Ringkasan 1

$\begin{array}{lr}\text { Pendahuluan } & 1\end{array}$

Masalah Definisi yang Kurang Tepat dan Saling Bertentangan 3

Petani Rakyat 5

Rangkaian Kesatuan (Continuum) Sistem Perladangan Berpindah Perambahan Hutan 6

$\begin{array}{ll}\text { Produksi Perkebunan Rakyat } & 7\end{array}$

$\begin{array}{lr}\text { Transmigrasi } & 8\end{array}$

$\begin{array}{lr}\text { Kepadatan Penduduk } & 10\end{array}$

Kegiatan Pembalakan dan Industri Perkayuan $\quad 12$

Perkebunan Besar dan Hutan Tanaman Industri 14

$\begin{array}{ll}\text { Tanaman Komersial di Perkebunan Besar } & 14\end{array}$

$\begin{array}{ll}\text { Hutan Tanaman Industri } & 15\end{array}$

$\begin{array}{ll}\text { Pedoman untuk Menentukan Laju dan Penyebab Deforestasi } & 16\end{array}$

Laju Perubahan Tutupan Hutan 16

$\begin{array}{ll}\text { Penyebab Perubahan Tutupan Hutan } & 17\end{array}$

$\begin{array}{lc}\text { Ringkasan dan Kesimpulan } & 18\end{array}$

$\begin{array}{lr}\text { Ucapan Terima Kasih } & 19\end{array}$

$\begin{array}{lr}\text { Daftar Pustaka } & 20\end{array}$

Paper ini tersedia juga dalam bahasa Inggris:

Rates and Causes of Deforestation in Indonesia: Towards a Resolution of the Ambiguities Occasional Paper No. 9, Dec 1996, Bogor, Indonesia: Center for International Forestry Research 


\title{
LAJU DAN PENYEBAB DEFORESTASI DI INDONESIA : PENELAAHAN KERANCUAN DAN PENYELESAIANNYA
}

\author{
William D. Sunderlin dan Ida Aju Pradnja Resosudarmo
}

\begin{abstract}
Ringkasan
Sudah ada beberapa penelitian utama mengenai laju dan penyebab deforestasi di Indonesia akhir-akhir ini dan sudah banyak literatur yang berkaitan dengan hal tersebut, namun masih belum ada konsensus dalam dunia penelitian mengenai masalah-masalah ini. Makalah ini mengulas aspek-aspek ketidakpastian dan kerancuan yang ada, dan mengajukan pertanyaan-pertanyaan yang harus dijawab untuk mendapatkan pokok permasalahan. Diantara pertanyaan-pertanyaan pokok adalah: (1) Bagaimanakah kita mendefinisikan "hutan", "deforestasi", dan "pelaku deforestasi" dalam konteks Indonesia?; (2) Apakah ciri-ciri sosio-ekonomis dan bagaimanakah praktek penggunaan lahan berbagai pelaku yang dikelompokkan begitu saja di bawah istilah "perladangan berpindah"?; (3) Apakah hubungan antara naiknya kepadatan penduduk dan hilangnya tutupan hutan merupakan hubungan sebab akibat atau hanya kebetulan?; (4) Mengapa beberapa pemegang konsesi nampaknya mengelola konsesinya dengan cukup baik, sedangkan banyak pemegang konsesi lainnya tidak?; (5) Apakah pengaruh nyata restrukturisasi ekonomi makro dan perubahan harga-harga komoditas sejak awal 1980-an pada tutupan hutan? Diusulkan pedoman-pedoman untuk perbaikan penelitian mengenai laju dan penyebab perubahan tutupan hutan. Makalah ini diakhiri dengan catatan akan perlunya menghilangkan kecenderungan mencari penyebab tunggal. Penjelasan-penjelasan yang meyakinkan tentu saja tidak sederhana, karena penyebab-penyebab deforestasi tertanam dalam kekuatan-kekuatan sosio-ekonomis yang mapan dan luas jangkauannya.
\end{abstract}

\section{PENDAHULUAN}

Indonesia menempati peringkat ketiga (sesudah Brazil dan Zaire) dalam kekayaan hutan hujan tropis, dan memiliki $10 \%$ dari sisa sumberdaya ini di dunia. Perkiraan resmi mengenai kawasan lahan hutan di Indonesia sangat bervariasi. REPELITA VI, 1994/951998/99 menyebutkan bahwa ada 92,4 juta ha lahan hutan pada tahun 1993 (RI 1994:312). Ini merupakan 48,1 \% dari keseluruhan daratan Indonesia. Inventarisasi Hutan Nasional, berdasarkan data satelit 1986-91 memperkirakan adanya 120,6 juta ha lahan hutan, yang meliputi 69\% daratan di negeri ini (tidak termasuk Pulau Jawa) (GOI/FAO 1996:17-18). Perkiraan penyebaran hutan di Indonesia adalah sebagai berikut: Kalimantan (32,0\% dari keseluruhan); Irian Jaya $(29,9 \%)$; Sumatra (20,8\%); Sulawesi $(9,7 \%)$; Maluku $(5,5 \%)$; dan daerah-daerah lain $(2,1 \%)$ (data dari GOI/FAO 1996:36).

Bermula dari pertengahan tahun 1960-an eksploitasi komersial hutan di pulau-pulau di luar pulau Jawa ${ }^{1}$ telah tumbuh dengan cepat dan Indonesia kini merupakan salah satu pengekspor kayu tropis yang terbesar di dunia (terutama kayu lapis). Pada tahun 1996 pemegang hak pengusahaan hutan (HPH) berjumlah 445 dan meliputi area seluas 54.060.599 ha. ${ }^{2}$ Pada tahun 1994 kayu dan produk-produk kayu menghasilkan sekitar US\$ 5,5 milyar pendapatan ekspor Indonesia, kira-kira $15 \%$ dari keseluruhan pendapatan ekspor (Economist Intelligence Unit 1995b:3). Ada kira-kira 700.000 orang yang dipekerjakan di sektor hutan secara resmi (World Bank 1995:1).

Dalam perjalanan perkembangan industri perkayuan, terjadi peningkatan besar dalam jumlah dan laju hilangnya tutupan hutan di Indonesia. Penelitian FAO tahun 1990 menunjukkan bahwa tutupan hutan di negeri ini telah berkurang dari $74 \%$ menjadi $56 \%$ dalam jangka waktu 30-40 tahun (FAO 1990:3). World Bank (1990:xx), mengacu pada penelitian yang dilakukan FAO, mencatat peningkatan dalam estimasi deforestasi setiap tahun: pada tahun 1970-an 300.000 ha/tahun; pada tahun 1981, 600.000 ha/tahun; pada tahun 1990 satu juta ha/tahun.

Orang cenderung berkesimpulan bahwa pertumbuhan industri perkayuan mengakibatkan peningkatan laju deforestasi yang dianggap cepat sekali, karena kedua fenomena itu terjadi pada saat yang bersamaan. Namun penjelasan lain menekankan bahwa deforestasi

\footnotetext{
Istilah "pulau-pulau di luar pulau Jawa” dimaksudkan untuk kawasan Indonesia di luar Pulau Jawa, Madura dan Bali.

2 Data dari komunikasi pribadi, Waskito Suryodibroto, Sekretaris Dirjen, Ditjen Pengusahaan Hutan, Departemen Kehutanan, Jakarta, Indonesia, 21 November 1996.
} 
Tabel 1: Perubahan pandangan mengenai penyebab deforestasi di Indonesia sejalan dengan waktu

\begin{tabular}{|c|c|c|c|c|c|c|c|}
\hline \multirow{4}{*}{ SUMBER } & \multicolumn{7}{|c|}{ JENIS PENYEBAB } \\
\hline & \multicolumn{5}{|c|}{ PELAKU } & \multicolumn{2}{|c|}{$\begin{array}{c}\text { PENYEBAB YANG } \\
\text { MENDASARI DEFORESTASI }\end{array}$} \\
\hline & \multicolumn{3}{|c|}{ petani rakyat } & \multirow[b]{2}{*}{$\begin{array}{l}\text { perkebunan } \\
\& \text { tanaman } \\
\text { keras }\end{array}$} & \multirow[b]{2}{*}{$\begin{array}{l}\text { industri } \\
\text { perkayuan }\end{array}$} & \multirow[b]{2}{*}{$\begin{array}{l}\text { pemerintah } \\
\text { /politik }\end{array}$} & \multirow[b]{2}{*}{$\begin{array}{l}\text { perkembang- } \\
\text { an ekonomi }\end{array}$} \\
\hline & $\begin{array}{l}\text { sistem } \\
\text { perladangan } \\
\text { berpindah }\end{array}$ & $\begin{array}{l}\text { transmigran } \\
\text { spontan }\end{array}$ & $\begin{array}{l}\text { transmigran } \\
\text { umum }\end{array}$ & & & & \\
\hline \multicolumn{8}{|l|}{$\begin{array}{l}\text { World Bank } \\
1990\end{array}$} \\
\hline \multicolumn{8}{|l|}{ FAO 1990} \\
\hline \multicolumn{8}{|l|}{ Dick 1991} \\
\hline WALHI 1992 & $\begin{array}{c}\text { dampak } \\
\text { dilebihkan }\end{array}$ & & & & & & \\
\hline $\begin{array}{l}\text { Barbier et al. } \\
\quad 1993\end{array}$ & \multicolumn{3}{|c|}{$\begin{array}{l}\text { pertumbuhan kepadatan penduduk dianggap } \\
\text { penyebab paling penting }\end{array}$} & & & & \\
\hline Ascher 1993 & & & & & & $\begin{array}{l}\text { Sekutu Peme- } \\
\text { rintah - Dephut }\end{array}$ & $\begin{array}{l}\text { diversifikasi } \\
\text { ekonomi }\end{array}$ \\
\hline \multicolumn{8}{|l|}{ Porter 1994} \\
\hline $\begin{array}{l}\text { Dauvergne } \\
1994\end{array}$ & & & & & $\begin{array}{c}\text { dampak } \\
\text { dikecilkan }\end{array}$ & & \\
\hline Thiele 1994 & \multicolumn{3}{|c|}{ dampak dilebih-lebihkan } & & $\begin{array}{l}\text { dampak } \\
\text { dikecilkan }\end{array}$ & & \\
\hline $\begin{array}{l}\text { World Bank } \\
1994\end{array}$ & $\begin{array}{c}\text { dampak } \\
\text { dilebihkan }\end{array}$ & & & & $\begin{array}{c}\text { dampak } \\
\text { dikecilkan }\end{array}$ & & \\
\hline Angelsen 1995 & $\begin{array}{c}\text { dampak } \\
\text { dilebihkan }\end{array}$ & & & & & $\begin{array}{l}\text { tuntutan lahan } \\
\text { pemerintah }\end{array}$ & $\begin{array}{l}\text { pengaruh harga } \\
\text { dari luar }\end{array}$ \\
\hline MOF 1995 & $\begin{array}{c}\text { dampak } \\
\text { dilebihkan }\end{array}$ & & & & & & \\
\hline Ross 1996 & & & & & & $\begin{array}{c}\text { koalisi } \\
\text { penguasa }\end{array}$ & \\
\hline Fraser 1996 & $\begin{array}{l}\text { kepadatan } \\
\text { penduduk }\end{array}$ & & & $\begin{array}{c}\text { dampak } \\
\text { dilebihkan }\end{array}$ & & & \\
\hline $\begin{array}{l}\text { Hasanuddin } \\
1996\end{array}$ & $\begin{array}{l}\text { petani rakyat } \\
\text { tidak bersalah }\end{array}$ & & & & & & \\
\hline Dove 1996 & $\begin{array}{c}\text { dampak } \\
\text { dilebihkan }\end{array}$ & & & & & ekonomi p & litik nasional \\
\hline
\end{tabular}

Petak yang diberi warna gelap menunjukkan bentuk pelaku/penyebab yang memegang peran utama dalam deforestasi.

di pulau-pulau di luar pulau Jawa terutama adalah sebagai akibat pertumbuhan kepadatan penduduk dan pertumbuhan jumlah petani kecil/rakyat di kawasankawasan ini. Data mengenai kepadatan penduduk di Indonesia menunjukkan korelasi negatif yang kuat dengan tutupan hutan (FAO 1990:10; Barbier et al, 1993; Fraser 1996). ${ }^{3}$

Saat ini pada dasarnya ada dua kubu dalam perdebatan yang berlangsung mengenai penyebab deforestasi di Indonesia (Tabel 1). Di satu pihak ada penjelasanpenjelasan yang memandang produksi petani kecil dan meningkatnya jumlah petani kecil sebagai penyebab utama deforestasi (FAO 1990; World Bank 1990; Barbier et al. 1993, Fraser 1996). Penjelasan tersebut cenderung memandang penduduk sipil dan terutama petani kecil, sebagai faktor utama dalam pembabatan tutupan hutan. Di pihak lain ada penjelasan-penjelasan yang, meskipun mengakui peran besar produksi petani kecil dalam deforestasi, lebih menekankan pada peranan pemerintah dan proyek-proyek pembangunannya, dan pada sektor industri perkayuan (Dick 1991; WALHI 1992; Ascher 1993; Dauvergne 1994; Porter 1994;

3 Flint (1994:1043) menunjukkan korelasi ini untuk Asia Tenggara secara keseluruhan. 
Thiele 1994; World Bank 1994; Angelsen 1995; Dove 1996; Hasanuddin 1996; Ross 1996).

Tabel 1 menunjukkan bergesernya "titik berat" penjelasan penyebab deforestasi akhir-akhir ini. Pada tahun 1990 World Bank dan FAO menyatakan penyebab utamanya adalah perladangan berpindah. Analisa-analisa berikutnya menyatakan bahwa peran perladangan berpindah dalam deforestasi telah terlalu dibesarbesarkan, dan peran sektor industri perkayuan kurang disoroti. Pemikiran baru ini terutama menyatakan bahwa sektor industri perkayuan memainkan peranan penting secara tidak langsung dalam deforestasi dengan kegiatannya mengeksploitasi hutan, yang kemudian diambil alih dan diusahakan oleh para petani kecil.

Perlu dicatat bahwa telah ada perubahan besar dalam pandangan World Bank, yang merupakan salah satu pemain kunci resmi dalam perdebatan ini. Pada tahun 1990, World Bank (1990:xxi) memperkirakan laju deforestasi tahunan antara 700.000 dan 1.200.000 ha, di mana konversi oleh petani kecil ditaksir sebesar $350.000-650.000$ ha dari keseluruhan angka laju deforestasi diatas, dan menekankan keprihatinannya pada sistem perladangan berpindah. Pada tahun 1994 World Bank (1994:ix, 19) menemukan bahwa pengelolaan konsesi hutan di pulau-pulau di luar pulau Jawa sebagai prioritas utama masalah lingkungan yang dihadapi negara ini dan mencatat bahwa peranan sistem pertanian berladang dalam deforestasi telah terlalu dibesar-besarkan dalam studi-studi sebelumnya.

World Bank (1994:51) mengacu pada penelitian Dick (1991), menyatakan bahwa program-program yang disponsori pemerintah (transmigrasi, perkebunan, kegiatan pembalakan) menyebabkan $67 \%$ dari semua deforestasi.

Perubahan dramatis pada pandangan World Bank tidak boleh diartikan sebagai tanda bahwa para peneliti telah semakin mengerti sampai sejauh mana tingkat deforestasi dan penyebabnya di Indonesia. Justru sebaliknya, nampaknya meskipun elemen-elemen penting telah berhasil diakumulasi, masih banyak ketidakpastian dan teka-teki yang dihadapi. World Bank (1994:19) mengakui bahwa taksiran laju tahunan deforestasi didasarkan pada data yang lemah. Bukannya mengajukan estimasinya sendiri yang telah diperbaharui, World Bank malahan hanya melaporkan berbagai estimasi yang dikemukakan pihak-pihak lain, dari 263.000 ha/tahun sampai 1.315.000 ha/tahun (World Bank: 1994:52). World Bank kelihatannya mendua dalam hal pelaku deforestasi. Di satu pihak lembaga ini membesarkan peranan industri perkayuan dan peranan program-program pemerintah dalam proses deforestasi, dan mengecilkan peranan sistem pertanian berladang; di pihak lain mengatakan bahwa pertanian rakyat merupakan "penyebab terbesar deforestasi" (World Bank 1994:53).

Ulasan atas beberapa literatur mengenai deforestasi di Indonesia menunjukkan bahwa ada dua penyebab utama kelemahan dasar pengetahuan masalah ini. Pertama, data primer yang dapat diandalkan mengenai laju dan penyebab perubahan tutupan hutan kurang sekali. ${ }^{4}$ Dick (1991:32) mengamati bahwa karena keterbatasan ini, estimasi tingkat dan penyebab deforestasi di Indonesia adalah "perkiraan semi-intelek" (semi-educated guesses). Kedua, para komentator mengenai masalah tersebut memakai istilah-istilah seperti "deforestasi" dan "perladangan berpindah" dengan beraneka arti. Kita lihat nanti bahwa hal ini mengakibatkan berbagai kekacauan dalam perdebatan mengenai masalah di atas.

Langkah yang paling berguna menuju peningkatan dasar pengetahuan mengenai deforestasi adalah mengadakan ulasan kritis mengenai literatur yang ada. Dengan cara ini kita dapat terlebih dahulu menetapkan 'tingkat kepercayaan' bagian-bagian yang relevan dari analisa yang telah dikerjakan, menentukan topik-topik yang memerlukan penelitian lebih jauh, dan mengusulkan pedoman untuk mengatasi kerancuan masalah.

Makalah ini akan mengulas literatur mengikuti langkah-langkah berikut. Pertama-tama akan ditelaah masalah konseptualisasi istilah "deforestasi" dan "pelaku deforestasi" yang tidak jelas. Kedua, akan dianalisa diskusi mengenai berbagai penyebab perubahan tutupan hutan. Urutannya adalah: petani kecil (perladangan berpindah dan "perambah hutan"; produksi perkebunan rakyat; transmigrasi umum; transmigrasi spontan; pertumbuhan jumlah penduduk); kegiatan pembalakan dan industri perkayuan; perkebunan dan hutan tanaman industri; kebijakan-kebijakan ekonomi makro; serta berbagai bentuk penyebab yang selama ini kurang diperhatikan dalam literatur. Ketiga, akan diusulkan pedomanpedoman untuk perbaikan penelitian mengenai laju dan penyebab perubahan tutupan hutan. Makalah ini akan ditutup dengan ringkasan permasalahan-permasalahan pokok yang memerlukan penelitian lebih jauh.

\section{MASALAH DEFINISI YANG KURANG TEPAT DAN SALING BERTENTANGAN}

Estimasi mengenai luas areal deforestasi rata-rata tahunan di Indonesia sangat berbeda-beda, mulai dari yang rendah seluas 263.000 ha (TAG 1991) sampai yang tinggi seluas 2.400 .000 ha (Hasanuddin 1996)

\footnotetext{
4 Estimasi deforestasi FAO (1990) mengandalkan berbagai taksiran tutupan hutan pada tahun-tahun yang berbeda; perubahan tutupan hutan kemudian diekstrapolasi pada tingkat propinsi berdasarkan data kepadatan penduduk (Sutter 1989:101-154). Estimasi World Bank (1990:3, 147) mengenai deforestasi mengandalkan kalkulasi bank dan survey suplai kayu. Estimasi perubahan tutupan hutan yang dapat diandalkan memerlukan diperbandingkannya gambar-gambar satelit yang berkesesuain selama beberapa tahun (Downton 1995:230).
} 
Tabel 2: Estimasi deforestasi setiap tahun di Indonesia (ribu ha)

\begin{tabular}{|c|c|c|c|c|c|c|c|c|}
\hline \multirow{2}{*}{$\begin{array}{l}\text { SUMBER } \\
\text { ESTIMASI }\end{array}$} & \multicolumn{8}{|c|}{ PELAKU } \\
\hline & $\begin{array}{c}\text { Perkembangan } \\
\text { Transmigrasi }\end{array}$ & $\begin{array}{l}\text { Tanaman } \\
\text { Perke- } \\
\text { bunan }\end{array}$ & $\begin{array}{l}\text { Pengusaha- } \\
\text { an Tanah } \\
\text { Sewa }\end{array}$ & $\begin{array}{l}\text { Transmi- } \\
\text { grasi } \\
\text { Spontan }\end{array}$ & $\begin{array}{l}\text { Pertanian } \\
\text { Tradisional }\end{array}$ & $\begin{array}{l}\text { Pemba- } \\
\text { lakan }\end{array}$ & $\begin{array}{l}\text { Keba- } \\
\text { karan } \\
\text { Hutan }\end{array}$ & TOTAL \\
\hline $\begin{array}{l}\text { World Bank } \\
1990\end{array}$ & \multicolumn{3}{|c|}{250} & \multicolumn{2}{|c|}{500} & 80 & 70 & 900 \\
\hline FAO 1990 & 300 & 274 & 85 & \multicolumn{2}{|c|}{461} & 80 & 113 & 1,315 \\
\hline TAG 1991 & 65 & 11.4 & 30.4 & \multicolumn{2}{|c|}{156.5} & TT & TT & 262.9 \\
\hline MOF 1992 & 300 & 160 & & \multicolumn{2}{|c|}{300} & 77 & 478 & 1,315 \\
\hline Dick 1991 & 78.4 & 11.4 & 30.4 & 178.5 & 135.5 & 120 & 70 & 623 \\
\hline $\begin{array}{l}\text { Sukarjo } \\
1996^{\mathrm{a}}\end{array}$ & TT & TT & TT & TT & TT & TT & TT & 809 \\
\hline $\begin{array}{l}\text { Hasanuddin } \\
1996\end{array}$ & TT & TT & TT & TT & TT & TT & TT & 2,400 \\
\hline
\end{tabular}

Empat baris pertama dalam tabel ini (World Bank 1990 sampai dengan MOF 1992) dikutip dari World Bank (1994:52). Data aslinya dimodifikasi untuk mencerminkan kenyataan bahwa kebanyakan sumber data tidak membedakan kategori "transmigrasi spontan" dan "pertanian tradisional". Tabel World Bank (1944:52) memberikan kesan yang keliru, bahwa keduanya dibedakan satu sama lain. Dick (1991) memberikan kontribusi nyata dengan mengakui perbedaan itu. TT artinya "tidak tersedia".

a Dilaporkan di Jakarta Post, 29 Mei 1996.

(lihat Tabel 2). Beberapa penulis melihat bahwa estimasi deforestasi di Indonesia digerogoti oleh penggunaan istilah "deforestasi" yang kurang jelas dan tidak konsisten. Diantara penulis yang paling vokal mengenai permasalahan ini adalah Dick (1991), Soemarwoto (1992), Saharjo (1994) dan Angelsen (1995). ${ }^{5}$ Kurang spesifiknya penggunaan istilah "deforestasi" mengakibatkan interpretasi data yang selektif dan karenanya benar-benar mengaburkan permasalahannya. Seperti yang kita lihat di bawah ini, kasus yang terburuk adalah, "deforestasi" bagi seseorang mungkin berarti "reboisasi (penghutanan kembali)" bagi orang lain. Masalah yang ada hubungannya dengan hal tersebut adalah bagaimana seseorang mengkonsepsualisasikan atau mendefinisikan "pelaku" deforestasi. Berikut beberapa kesulitan utama dalam penggunaan istilah "deforestasi" dan "pelaku deforestasi".

(1) Apakah "deforestasi" hanya berarti hilangnya tutupan hutan secara permanen, atau baik permanen maupun sementara? Dua diantara penelitian utama (FAO 1990; World Bank 1990) secara tersirat menyatakan bahwa hilangnya tutupan hutan secara permanen ataupun sementara merupakan deforestasi. Dengan demikian, berarti mereka menganggap kawasan perladangan berpindah yang akan kembali menjadi hutan sekunder juga merupakan deforestasi. Dengan definisi seperti itu, kawasan yang mengalami deforestasi maupun peranan sistem perladangan berpindah dalam deforestasi secara keseluruhan menjadi sangat besar.

\footnotetext{
5 Sayer dan Whitmore (1991) dan Grainger (1993) mencatat kesulitan membuat perbandingan estimasi hilangnya tutupan hutan secara internasional karena dipakainya definisi-definisi yang berbeda atas istilah-istilah dan konsep-konsep kunci.
} 
(2) Apakah "deforestasi" berarti hilangnya tutupan hutan untuk segala macam penggunaan, atau apakah artinya hilangnya tutupan hutan yang tidak dapat menghasilkan kayu? Definisi yang tersirat dalam istilah deforestasi World Bank 1990 (hal. 3) didasarkan pada pandangan yang kedua.

(3) Apakah "deforestasi" berarti hilangnya tutupan hutan saja, atau apakah itu juga berarti hilangnya berbagai ciri-ciri kelengkapan hutan (forest attributes), misalnya kelebatannya, strukturnya dan komposisi spesiesnya? Saharjo (1994) menunjukkan bahwa bila menyangkut tutupan hutan saja, luas kawasan yang hilang lebih kecil daripada bila yang dimaksud menyangkut hilangnya berbagai ciri-ciri kelengkapan hutan. Degradasi hutan merupakan masalah penting dalam penilaian perbandingan efek lingkungan yang ditimbulkan oleh kegiatan pertanian rakyat dan kegiatan pembalakan. Pada sistem perladangan berpindah, misalnya, lahan yang ditanami sering dikatakan sebagai lahan yang telah mengalami "deforestasi", namun lahan ini kelak dapat kembali menjadi tutupan hutan. Hutan-hutan yang ditebang dalam kegiatan pembalakan secara besar-besaran sering tidak dianggap telah mengalami "deforestasi", hanya karena masih banyak pohon yang tegak setelah tebang pilih, tetapi dalam beberapa kasus mungkin banyak sekali fungsi lingkungan yang telah hilang dari hutan tersebut.

(4) Apakah yang disebut dengan "pelaku deforestasi" adalah mereka yang membuka tutupan hutan, atau mereka yang kemudian menghalangi pertumbuhan kembali tutupan hutan? Apabila pengertian pertama yang diakui, maka perusahaan-perusahaan penebangan hutan (HPH) memainkan peranan yang lebih besar dalam deforestasi. Dan apabila pengertian kedua yang diakui, maka para petani kecil, yang kadang-kadang menduduki lahan yang telah dibuka terlebih dahulu oleh kegiatan pembalakan (HPH), yang dianggap berperanan lebih besar. Beberapa pengamat telah menunjukkan bahwa secara praktis tidak mungkin memilah-milah peranan pelaku-pelaku deforestasi dalam suatu lokasi yang sama (contoh: World Bank 1990:xx; Ahmad 1995:3).

(5) Apakah "pelaku deforestasi" sebaiknya didefinisikan secara tepat dalam pengertian pemanfaatan akhir lahan hutan yang telah dibuka, dan bukan berdasarkan tindakan dan tujuan mereka yang sesungguhnya membuka hutan? Barbier et al. (1993:7) mengusulkan jalan pemikiran yang demikian dan berpendapat bahwa deforestasi di Indonesia banyak terjadi pada lahan yang dimaksudkan untuk dikonversikan menjadi lahan pertanian, jadi peranan penyebab deforestasi dipegang oleh pertumbuhan kegiatan pertanian.

Masalah lain yang berkaitan adalah beragamnya perspektif para pengamat mengenai nilai utama hutan, misalnya dalam hal penggantian hutan alam dengan hutan tanaman industri. ${ }^{6}$ Para komentator yang mewakili pemerintah atau industri mungkin akan mendukung perkembangan kegiatan ini, karena hasil kayu gelondongan dari hutan tanaman industri per hektar dapat lebih besar dibandingkan dengan hasil dari hutan alam. Para komentator yang mewakili kelompok lingkungan dan masyarakat di sekitar dan di dalam hutan memandang situasi ini dengan kacamata berbeda, karena proses ini dapat membahayakan keaneka-ragaman hayati dan kepentingan masyarakat yang tinggal di sekitar dan di dalam hutan. Dari kacamata pendukung lingkungan, pembangunan hutan tanaman industri dapat dipandang sebagai "deforestasi", sedangkan dari kacamata pemerintah dan industri hal ini dipandang sebagai "reforestasi". Keprihatinan ini tercermin secara ringkas dalam judul dokumen WALHI/YLBHI (1992) Mistaking Plantations for Indonesia's Tropical Forests (Kekeliruan Menafsirkan Hutan Tanaman Industri Sebagai Hutan Tropis Indonesia). Pandangan-pandangan berbeda yang mewakili kepentingan-kepentingan tertentu mengenai berbagai jenis hutan, dapat menyebabkan interpretasi yang berbeda atas data primer yang sama.

Seharusnya jelas bahwa pemakaian istilah-istilah dan konsep-konsep penting secara lebih akurat merupakan prasyarat dalam meningkatkan kualitas penelitian mengenai perubahan tutupan hutan. Pada bagian 6 kami menganjurkan pemakaian metodologi baru yang dikembangkan oleh FAO (1996) untuk menganalisa perubahan tutupan hutan. Metodologi ini mencakup definisi yang tepat mengenai "hutan" dan "deforestasi" yang - apabila diterapkan secara sistematis - dapat mencegah kekisruhan dan interpretasi selektif atas data tutupan hutan.

\section{PETANI RAKYAT}

Dalam bagian ini kami ulas literatur terbaru mengenai peranan petani rakyat atau petani kecil dalam perubahan tutupan hutan di Indonesia. Ulasan ini meliputi: rangkaian kesatuan (continuum) "sistem perladangan berpindah - perambahan hutan", produksi perkebunan rakyat; transmigrasi umum; transmigrasi spontan (swakarsa); dan peranan kepadatan penduduk dalam hilangnya tutupan hutan.

\footnotetext{
6 Durand (1944:337) mencatat bahwa cara-cara yang berbeda dalam mendefinisikan hutan primer mengakibatkan kalkulasi yang berbeda mengenai berapa jumlah hutan semacam itu yang masih tersisa di Indonesia.
} 


\section{Rangkaian Kesatuan (Continuum) Sistem Perladangan Berpindah - Perambahan Hutan}

"Sistem perladangan berpindah " mempunyai arti yang berbeda bagi orang yang berbeda. Kekisruhan terminologi ini menghambat usaha-usaha untuk memahami hubungan antara sistem pertanian rakyat dengan perubahan tutupan hutan. Weinstock dan Sunito (1989:5) mengamati bahwa "meskipun setelah menelusuri terminologi, kita dihadapkan pada berderet-deret definisi mengenai bentuk produksi pertanian ini, dan setiap definisi mencerminkan pandangan yang berbeda mengenai jenis kegiatan apa yang harus atau yang tidak boleh dimasukkan.” Beberapa pemakaian istilah tersebut hanya mengacu pada sistem budidaya tradisional yang lestari berkelanjutan, dengan masa bera yang panjang; sistem ini sering dikatakan sejalan dengan konservasi hutan-hutan primer. Penulis-penulis lain memakai istilah "perladangan berpindah" untuk sistem pertanian berotasi yang bisa mempunyai masa bera yang panjang, bisa juga tidak; dan bisa dikaitkan dengan konservasi hutan jangka panjang, bisa juga tidak. Penulis lain lagi menyamakan "perladangan berpindah" dengan sistem pertanian rakyat secara umum di pulau-pulau di luar Jawa - pemakaian istilah yang mengabaikan kenyataan bahwa banyak petani rakyat yang dalam usahanya tidak menjalankan bentuk rotasi apapun.

Weinstock dan Sunito (1989:20-21) menyarankan perbedaan fundamental antara "peladang berpindah" dan "perambah hutan". " "Peladang berpindah" dijabarkan sebagai orang-orang "yang melaksanakan sistem pertanian berotasi dengan masa bera yang lebih lama daripada masa tanam .... Kecuali apabila dihadapkan oleh tekanan penduduk atau kendala-kendala lain, lahan hanya dipakai satu sampai tiga tahun dan diberakan (tidak diusahakan) untuk masa yang relatif lama (sampai duapuluh tahun atau lebih)" (hal. 20). "Para perambah hutan" dijabarkan sebagai orang-orang "yang mungkin menggunakan sistem tebas bakar vegetasi yang ada, tetapi dengan niatan utama untuk mendirikan usaha pertanian yang permanen atau semipermanen. Meskipun mungkin ditanam beberapa jenis tanaman pangan untuk memenuhi kebutuhan sendiri, penanaman tanaman komersial (seringkali tanaman tahunan) merupakan fokus budidayanya. Biasanya lahannya tidak diberakan, tetapi dipergunakan terus menerus dan hanya ditinggalkan setelah kesuburannya hampir atau telah hilang samasekali, karena tidak ada rencana jangka panjang untuk kembali ke lokasi yang sama (hal. 21)."

Agar kita dapat benar-benar memahami peranan petani kecil dalam perubahan tutupan hutan di Indonesia, perlu sekali menyadari dan mengakui adanya rangkaian kesatuan usaha tani mulai dari sistem perladangan berpindah tradisional (dengan masa bera panjang dan konservasi hutan jangka panjang) pada ujung yang satu, dan budidaya "perambah hutan" (yang seringkali berakibat degradasi dalam jangka panjang dan deforestasi) pada ujung yang lain. Di Indonesia ada polarisasi ideologi di mana wakil-wakil pemerintah dan LSM Lingkungan cenderung tidak mengakui adanya rangkaian kesatuan tersebut.

Pihak pemerintah mencela perambahan hutan sebagai merusak lingkungan dan seringkali tidak membedakannya dengan sistem perladangan berpindah. Apabila pemerintah serius dalam melestarikan hutan, pemerintah harus mendukung usaha pertanian tradisional yang konsisten dengan tujuan konservasi hutan jangka panjang. ${ }^{8}$ Sebaliknya LSM-LSM Lingkungan cenderung memusatkan perhatiannya pada budidaya perladangan berpindah tradisional ${ }^{9}$ dan mengesampingkan usaha-usaha pertanian yang kurang lestari berkelanjutan. Nampaknya aktivis-aktivis ini takut bahwa pengakuan atas adanya usaha-usaha pertanian rakyat yang tidak lestari berkelanjutan akan melemahkan pernyataan mereka bahwa penduduk yang tinggal di pinggir hutan memiliki kearifan dalam mengelola hutan. Pengakuan akan keseluruhan rangkaian kesatuan berbagai usaha pertanian justru akan memperkuat, bukannya melemahkan posisi LSM karena dua hal. Pertama, ini akan menunjukkan pengakuan atas rumitnya perubahan sosial pedesaan. Kedua, ini akan menunjukkan keprihatinan terhadap perambah hutan, yang seperti halnya para peladang berpindah, sebenarnya juga merupakan korban proses perubahan sosial yang cepat sekali.

Terobosan penting dalam pemahaman yang lebih baik mengenai peranan sistem perladangan berpindah dalam deforestasi dicapai melalui kritik Dick (1991) terhadap penelitian-penelitian World Bank (1991) dan FAO (1990). Berdasarkan perhitungan berikut ini, World Bank (1990) menyatakan bahwa sistem perladangan berpindah memegang peranan yang sangat besar dalam deforestasi. Luas areal yang dilaporkan dipakai untuk perladangan berpindah dalam tiga

\footnotetext{
Ini sejalan dengan perbedaan yang dibuat oleh Myers (1995) antara Peladang “berpindah” dan Peladang “yang dipindahkan”.

8 Lihat Zerner (1992) untuk argumentasi yang mendukung pandangan ini.

9 Para aktivis LSM telah secara tepat berkeras memakai istilah "perladangan gilir-balik” daripada "perladangan berpindah" untuk menggambarkan sistem perladangan tradisional dengan masa bera panjang yang lestari. Mereka menolak anggapan -yang tersirat dalam istilah "berpindah" bahwa para petani ini pada dasarnya nomadik dan menetapkan haknya atas lahan-lahan hutan dengan cara sembarangan. Meskipun penemuan istilah ini sangat berguna, tetapi tidak dapat dipakai untuk menutupi kenyataan bahwa ada sistem-sistem nomadik dalam tataguna lahan.
} 
propinsi di Indonesia pada tahun 1990 adalah 14 juta ha di Sumatra, 11 juta ha di Kalimantan dan 2 juta ha di Irian Jaya (data RePPProT, seperti disitir oleh World Bank (1990:3). Keseluruhan areal sejumlah 27 juta ha meluas dengan laju $2 \%$ setahun, yang menurut World Bank (1990:3) berarti deforestasi seluas kira-kira 500.000 ha per tahun - jelas sekali ini merupakan penyebab terbesar deforestasi. Asumsi FAO (1990) kira-kira juga demikian.

Dick (1991) mengkritik asumsi yang mendasari penelitian-penelitian ini dengan menunjukkan bahwa para peneliti itu mencampurkan begitu saja ke dalam kelompok "konversi oleh petani kecil" atau "sistem perladangan berpindah", baik budidaya "perladangan berpindah tradisional", yang dipandangnya merupakan kegiatan yang tidak merusak, maupun "transmigrasi spontan" yang dipandangnya melaksanakan kegiatankegiatan yang tidak lestari berkelanjutan dan karenanya bertanggung jawab atas bagian terbesar deforestasi ${ }^{10}$. Dia berpendapat bahwa apabila keduanya dibedakan, maka para peladang berpindah tradisional hanya bertanggung jawab atas $21 \%$ keseluruhan deforestasi, bukannya yang terluas seperti dinyatakan oleh penelitian World Bank dan FAO (hal. 32). Dia yakin bahwa angka inipun telah melebihkan-lebihkan sumbangan sistem perladangan berpindah tradisional terhadap deforestasi, sebab banyak hutan yang mereka buka adalah bagian dari tanah adat yang telah lama dirotasikan (hal. 32). Selain itu dikemukakannya bahwa para peladang berpindah tradisional "peralatannya tidak memadai untuk mengkonversi hutan, kecuali hutan primer yang paling terbuka" (hal. 27).

Penilaian deforestasi World Bank berikutnya, sebagaimana disebutkan diatas, memandang praktek sistem perladangan berpindah tradisional dengan lebih ramah. Laporannya menyatakan bahwa sistem perladangan berpindah tradisional mungkin tidak begitu merusak seperti yang diperkirakan sebelumnya (World Bank 1994:19). Penelitian Colfer dan Dudley (1993) pada empat kelompok masyarakat di sekitar dan di dalam hutan di Kalimantan Timur juga mendorong pandangan yang lebih baik terhadap para peladang berpindah tradisional, dengan menunjukkan bahwa mereka mampu mengelola sumberdaya alam secara lestari berkelanjutan dan bahwa sistem pertanian mereka, meskipun menghasilkan panen padi yang rendah, sebenarnya menghasilkan berbagai produk berharga (kayu, hasil hutan non kayu, makanan, obat-obatan) yang cenderung diabaikan dalam penelitian lain.
Tetapi tidak jelas benar seberapa pentingnya keberadaan para peladang berpindah tradisional di pulaupulau di luar Jawa. World Bank (1994:19) mengacu pada penelitian baru, menyatakan bahwa "masyarakat tradisional mungkin jauh lebih besar jumlahnya daripada yang diperkirakan semula." Namun demikian, pengamat-pengamat lain menyatakan bahwa peladang berpindah tradisional jumlahnya sedikit dan sedang mengalami transformasi yang pesat dalam sistem budidaya mereka. Tomich dan van Noordwijk (1995:3) mengatakan bahwa budidaya perladangan berpindah tradisional "boleh dikatakan telah punah" di Sumatra. Potter (1993:109) mengacu pada studi WWF yang menunjukkan bahwa sistem "tradisional" telah menjadi modern, misalnya dengan penggunaan gergaji mesin. Kartawinata et al. (1989:603) mengamati bahwa pada beberapa kawasan di Kalimantan Timur yang dinyatakan kawasan perladangan berpindah, para produsen mengembangkan tanaman tahunan yang dipelihara selama sepuluh tahun atau lebih.

Apakah yang bisa kita tarik dari adanya beraneka pandangan yang satu sama lain sangat berbeda mengenai ciri-ciri utama sistem perladangan berpindah - dan yang lebih umum mengenai petani kecil/rakyat - di luar Jawa? Jelas bahwa pemahaman proses perubahan tutupan hutan di Indonesia akan sangat tergantung pada klasifikasi yang cermat dan pengetahuan mengenai ciri-ciri berbagai jenis petani kecil di dalam masyarakat yang tinggal di sekitar dan di dalam hutan. Weinstock dan Sunito (1989:37-38) mendapatkan bahwa diperlukan informasi mengenai hal-hal berikut: (1) lahan yang digunakan untuk perladangan berpindah digolongkan berdasarkan bentuk lahannya (lereng, dll.); (2) laju perubahan luas lahan yang digunakan untuk kegiatan perladangan berpindah sejalan dengan waktu; (3) perubahan pola sistem perladangan berpindah sejalan dengan waktu; dan (4) data mengenai pendatang yang masuk akibat industri pembalakan (HPH) dan dampaknya terhadap lahan hutan. Data-data ini, serta data perkebunan rakyat (lihat di bawah), akan sangat membantu. Penelitian akhir-akhir ini telah mengarah kepada hal-hal tersebut, tetapi masih banyak yang harus dilakukan. ${ }^{11}$

\section{Produksi perkebunan rakyat}

Disamping "perladangan berpindah" dan "perambahan hutan" ada lagi sistem usaha tani yang penting di pulau-pulau di luar pulau Jawa: perkebunan rakyat.

\footnotetext{
10 Dick (1991:30) juga menunjukkan bahwa penelitian-penelitian World Bank dan FAO memakai seluruh data hasil estimasi RePPProT untuk luas areal lahan yang dipakai untuk perladangan berpindah, termasuk semak-semak dan padang rumput, untuk mengestimasi deforestasi. Menurut dia cara demikian tidak tepat karena banyak padang rumput dan semak-semak yang alamiah dan sudah lama ada, dan karena petani-petani tertentu telah membudidayakan kawasan-kawasan ini sejak lama.

11 Lihat misalnya: BAPPEDA dan PPKD 1995; DepHut 1995; DepTrans dan YDWL 1996; Endogeotic Visicon 1996.
} 
Perkebunan rakyat sering tercakup dalam istilah umum "sistem perladangan berpindah", karena banyak peladang berpindah membudidayakan tanaman perkebunan/ tanaman keras. Tetapi perkebunan rakyat harus dilihat sebagai kategori analisa yang berbeda, karena meskipun berkaitan erat dengan sistem perladangan berpindah, perkebunan rakyat cenderung dilaksanakan pada jenis lahan yang berbeda dan mengikuti logika produksi yang samasekali berbeda (Dove 1993).

Perkebunan rakyat besar implikasinya terhadap luas tutupan hutan, karena sering diusahakan di hutan yang sudah dibuka dan karena berkembang dengan pesat akhir-akhir ini. Barlow dan Tomich (1991:32) mencatat bahwa kira-kira $20 \%$ dari seluruh lahan pertanian di Sumatra dan Kalimantan merupakan perkebunan. Pada tahun 1994 terdapat 8,89 juta ha lahan yang ditanami dengan tiga jenis utama tanaman perkebunan di Indonesia, dengan pembagian sebagai berikut: karet (39\%); kelapa (41\%); dan kelapa sawit (20\%) (PDP 1996). Proporsi areal tanaman perkebunan tersebut di propinsi-propinsi utama pada tahun 1988 adalah: Sumatra (55\%); Jawa (15\%); Kalimantan (13\%); Sulawesi (9\%); dan Nusa Tenggara (5\%) (Dick 1991:25). (Catatan: data ini adalah data produksi perkebunan rakyat dan perkebunan besar). Indonesia adalah produsen karet alam nomor dua di dunia (kirakira tiga perempatnya adalah karet rakyat), produsen minyak kelapa sawit kedua terbesar (kebanyakan dari perkebunan besar), produsen kopi nomor tiga di dunia (95\% adalah hasil perkebunan rakyat), dan keempat terbesar dalam produksi coklat (Economist Intelligence Unit 1995a:29-31). Hampir seluruh produksi kelapa/ kopra berasal dari perkebunan rakyat (World Bank 1996:164).

Mungkin ada hubungan erat antara produksi perkebunan rakyat dan deforestasi. Chomitz dan Griffiths (1996) menemukan bahwa tanaman keras hasil perkebunan rakyat, dan bukannya kegiatan perladangan berpindah untuk memenuhi kebutuhan pokok, juga berperan penting dalam deforestasi di Indonesia; diantara berbagai jenis tanaman perkebunan, karet nampaknya mempunyai hubungan yang paling erat dengan deforestasi. Karet merupakan sumber pendapatan tunggal terbesar dalam bidang pertanian di Indonesia (US\$ 1,5 milyar pada tahun 1994-95) dan nilainya bertambah dua kali lipat pada periode 19841995 (BankDunia 1996:141). Pada periode 1982-1994 produksi tanaman perkebunan meningkat dengan laju berikut: karet dari 900 menjadi 1.499 ton (66\%); kela- pa dari 1.718 menjadi 2.631 ton (60\%); dan kopi dari 281 menjadi 446 ton (55\%) (World Bank 1996:163).

Ada kemungkinan penanaman pohon karet akan meningkat sehubungan dengan fungsinya sebagai bukti pemilikan lahan, di daerah-daerah dimana terdapat banyak persaingan dalam pemilikan lahan. Dove (1993:142) mengatakan bahwa di daerah Kantu di Kalimantan Barat, "menanam pohon karet mungkin penting sekali sebagai cara memperoleh jaminan hak atas tanah ... taktik ini dipakai melawan penyerobotan tanah bukan hanya oleh orang-orang dari suku lain, tetapi juga oleh pemerintah". Angelsen 1995:17241725) mengamati bahwa di propinsi Riau, Sumatra, penanaman pohon karet merupakan suatu cara untuk "memperoleh dan mengamankan hak-hak atas tanah, sesuai dengan hukum adat dan hukum negara".

\section{Transmigrasi}

Data sensus tahun 1990 menunjukkan bahwa 108 juta (60\%) dari 180 juta penduduk Indonesia tinggal di Pulau Jawa dan Madura (Economist Intelligence Unit 1995a:11), kawasan yang hanya merupakan $7 \%$ luas daratan di negeri ini. Kepadatan penduduk pulau Jawa merupakah salah satu yang tertinggi di dunia. Sejak awal abad keduapuluh telah banyak usaha-usaha untuk mendorong keluarga-keluarga pindah dari pulau Jawa ke pulau-pulau lain untuk mengurangi tekanan penduduk, kemiskinan dan degradasi lahan. Ada dua jenis transmigran: transmigran "umum" mendapatkan bantuan penuh dari pemerintah, sedangkan transmigran "spontan" hanya menerima sebagian atau tidak menerima bantuan pemerintah sama sekali (lihat di bawah). ${ }^{12}$

Telah terjadi lonjakan tinggi dalam jumlah keluarga transmigran pada dekade-dekade terakhir ini. Pada periode 1950-1979 jumlah rata-rata transmigran setahun adalah $6.570 \mathrm{kk}$; pada periode 1980-1984 jumlahnya naik menjadi $73.200 \mathrm{kk} \cdot{ }^{13}$ Dick (1991:27-29) mengamati bahwa ada perbedaan besar dalam data jumlah transmigran dari dua buah sumber yang berbeda. Pada periode 1974-1989 Departemen Transmigrasi (MOT) menyatakan bahwa ada $664.000 \mathrm{kk}$ transmigran umum, sedangkan Kelompok Penasehat Transmigrasi (TAG) menyatakan ada $323.000 \mathrm{kk}$ (Dick 1991:28). Pada periode yang sama, Departemen Transmigrasi memperkirakan ada 455.000 transmigran spontan; sedangkan TAG tidak memberikan data. Persentasi penyebaran tujuan transmigrasi selama REPELITA V (1989/90-1993/94) adalah: Sumatra (53\%); Kalimantan

\footnotetext{
12 Sebenarnya istilah "spontan" tidak tepat disini, karena mengandung pengertian kurangnya perencanaan dari pihak keluarga transmigran (pengamatan dilakukan oleh Chris Benett berdasarkan komunikasi pribadi). Kebanyakan keluarga tersebut mempunyai banyak pertimbangan untuk pindah, apakah mereka menerima bantuan penuh, sebagian atau tidak menerima bantuan. Kami pakai istilah itu disini dengan terpaksa, untuk mempertahankan kontinuitas pembicaraan mengenai perbedaan antara "umum" dan “spontan" (e.g., Dick 1991; World Bank 1994).

13 Didapat dari data Departemen Transmigrasi dan World Bank (1988:xxiii).
} 
(23,5\%); Sulawesi (12,6\%); Irian Jaya dan Maluku $(9,2 \%)$; dan lokasi-lokasi lain $(1,75 \%) .{ }^{14}$ Diproyeksikan bahwa dalam periode 1994-1999 (REPELITA VI), akan ada penambahan sejumlah $350.000 \mathrm{kk}$ transmigran umum dan $250.000 \mathrm{kk}$ transmigran spontan (Dephut 1995:2).

\section{Dampak transmigrasi umum}

Dampak transmigrasi umum pada tutupan hutan di luar Jawa dan Madura dapat diklasifikasikan ke dalam tiga kategori: dampak langsung yakni hilangnya tutupan hutan untuk lokasi transmigrasi; pindahnya transmigran dari lokasi yang ditentukan karena penghasilan mereka tidak mencukupi; dan adanya tekanan lahan (land pressure) bagi keluarga-keluarga non-transmigran di sekitar lokasi transmigrasi yang diakibatkan oleh desakan para transmigran.

1. Pembabatan tutupan hutan. Pada pertengahan tahun 1980-an LSM-LSM internasional mengatakan bahwa program transmigrasi bertanggungjawab atas sejumlah besar deforestasi di Indonesia (lihat khususnya Secrett 1986). Setelah tuduhan itu dilancarkan, beberapa peneliti kemudian menyatakan bahwa jumlah deforestasi yang diakibatkan oleh transmigrasi umum sangat dibesar-besarkan. Whitten (1987:241-243), menggunakan data propinsi mengenai tutupan hutan dan pembukaan lahan untuk transmigrasi umum, menunjukkan bahwa pada tahun 1979-84 program transmigrasi yang resmi mengakibatkan konversi kurang dari 1\% keseluruhan luas hutan. ${ }^{15}$ Whitten (1987:241-243) memperkirakan bahwa 30-50\% dari lahan yang dibuka untuk transmigrasi asalnya berhutan. Pembetulan terhadap perkiraan terdahulu yang berlebihan (overestimation) beresiko melantur terlalu jauh kearah sebaliknya. Perhitungan yang memadai mengenai dampak transmigrasi terhadap lingkungan harus mencakup tidak saja lahan yang dibuka untuk transmigran umum, tetapi juga mencakup lahan lain yang dibuka oleh transmigran umum tersebut akibat penghasilan yang tidak mencukupi, serta lahan yang dibuka oleh transmigran "spontan". Whitten (1987:242) mencatat bahwa "transmigran swakarsa (tanpa bantuan pemerintah)" jumlahnya dua kali lipat transmigran umum. Ia mengesampingkan pentingnya sebagian besar konversi hutan tersebut, dengan mengatakan bahwa lahan tersebut memang dijatahkan untuk konversi menjadi lahan per- tanian. Sekalipun ini benar, perlu diingat bahwa belum pernah ada basis rasional dan obyektif dalam penentuan lahan konversi (Dick 1991:19).

Dick (1991:30) juga meragukan estimasi berlebihan mengenai pembukaan hutan akibat transmigrasi. Ia berpendapat bahwa estimasi lama mengenai besarnya deforestasi yang diakibatkan oleh transmigrasi umum telah dilebih-lebihkan karena para peneliti menganggap bahwa semua lahan yang dijatahkan untuk transmigrasi telah dikonversikan untuk itu, padahal kenyataannya sebagian besar dari lahan ini belum dikonversikan. Perhitungannya sendiri mengenai deforestasi akibat transmigrasi umum dalam periode 1979-1989 adalah 78.500 ha per tahun. Ia mendasarkan perhitungannya pada asumsi bahwa 3,0 ha lahan hutan dibuka untuk setiap kk transmigran $-2,0$ ha untuk pertanian dan 1,0 untuk infrastruktur (hal. 31-32). ${ }^{16}$ Perhitungan Dick salah dalam dua hal. Pertama, ia menyamakan pembukaan lahan dengan deforestasi, sedangkan kita tahu bahwa sebagian dari lahan yang dibuka untuk transmigrasi tidak mengalami deforestasi karena asalnya memang tidak berhutan (lihat diatas). Kedua, Dick lalai menindaklanjuti persepsinya sendiri (hal. 29) bahwa 2,0 ha lahan pertanian untuk tiap keluarga tidak mencukupi, dan bahwa deforestasi lebih lanjut akan terjadi saat penghuninya telah menguras kesuburan lahan tersebut. Kesalahan pertama cenderung memperkirakan jumlah hutan yang dibuka akibat transmigrasi umum lebih besar dari yang sebenarnya, sedangkan yang kedua lebih kecil dari yang sebenarnya.

\section{Perpindahan akibat penghasilan tidak mencukupi.} Sampai pertengahan 1980-an, lokasi transmigrasi umum ditujukan untuk menghasilkan tanaman pangan (terutama padi) pada lahan tiap keluarga sebesar 2,0 ha. Ternyata ini tidak memadai di berbagai lokasi, karena disamping luas lahan tidak mencukupi, juga karena tanah yang relatif kurang subur tidak mendukung budidaya padi dengan sarana produksi (input) yang rendah. Pada pertengahan 1980-an ditemukan bahwa 40-80\% penghasilan transmigran umum didapatkan dari pekerjaan di luar lahannya (World Bank 1988:xxvii). Banyak transmigran terjerat lingkaran setan; mereka mencari penghasilan di luar lokasi transmigrasi karena penghasilan dari lahan di lokasi transmigrasi tidak mencukupi, sehingga potensi penghasilan di lokasi transmigrasi tersebut tidak dikembangkan sepenuhnya

\footnotetext{
14 Kalkulasi didasarkan pada data DepTrans (1995: Lampiran 12).

15 Rujukan lain mengenai efek transmigrasi pada tutupan hutan adalah World Bank (1988;xxxi) dan McClellan (1992).

16 Secara spesifik, hasil estimasi itu didapat dengan perhitungan demikian: Dick lebih mempercayai data TAG daripada data DepTrans mengenai jumlah transmigran, di mana dia memperkirakan ada $261.565 \mathrm{kk}$ transmigran umum pada periode 1979-1989 (REPELITA III dan IV). Dikalikannya angka ini dengan 3,0 ha setiap kk, jadi perkiraan jumlah keseluruhan areal yang punah hutannya selama periode tersebut adalah 784.695 ha. Kemudian hasil perhitungan ini dibaginya dengan 10 untuk mendapatkan laju deforestasi rata-rata per tahun 78.500 ha.
} 
karena mereka harus bekerja di luar lokasi (RePPProT 1990:41). Sedikit sekali informasi mengenai proporsi transmigran umum yang beralih ke sistem perladangan berpindah atau menjadi perambah hutan. ${ }^{17}$ Telah ditunjukkan bahwa banyak transmigran menjalankan bentuk perladangan berpindah yang tidak lestari berkelanjutan karena mereka tidak mempunyai pengetahuan mengenai bentuk tradisional sistem perladangan berpindah dan karena mereka tidak mempunyai jaminan hak atas tanah (tenure security).

Sejak awal 1980-an, program transmigrasi telah semakin banyak berpaling dari tanaman pangan ke tanaman perkebunan (karet, kelapa, kelapa sawit, dll.), dengan asumsi bahwa bentuk tataguna lahan ini lebih sesuai dan lebih menguntungkan di pulau-pulau di luar Jawa. Perubahan kearah tanaman perkebunan juga penting karena merupakan sumbangan bagi usaha negara untuk diversifikasi ke arah ekspor non-migas (RePPProT 1990:41). Proyeksi sementara menunjukkan bahwa apabila sudah berkembang sepenuhnya, tanaman perkebunan akan meningkatkan penghasilan petani kecil dua kali lipat dibandingkan tanaman pangan (World Bank 1988:xxxix). Data nasional mengenai seberapa jauh perubahan ke arah tanaman perkebunan telah meningkatkan kecenderungan mencari penghasilan di luar lokasi transmigrasi tidak tersedia. Namun studi kasus di Propinsi Riau, Sumatra, memberikan gambaran yang mengecewakan (lihat Holden dan Hvoslef 1995; Holden et al. 1995).

3. Tekanan atas tanah yang diakibatkan oleh transmigrasi. Pemukiman transmigrasi seringkali dibangun bersebelahan dengan atau kadang-kadang di tengah-tengah masyarakat peladang berpindah. Jadi pemukimanpemukiman transmigrasi dapat mengurangi jumlah lahan yang tersedia untuk penggiliran pada sistem perladangan berpindah tradisional. Ditambah dengan meningkatnya tekanan penduduk asli, hal ini dapat memperpendek masa bera, menyebabkan eksploitasi berlebihan pada tanah yang tidak subur, mendorong perubahan kearah sistem pertanian menetap dan memacu spekulasi tanah. Angelsen (1995) melihat kecenderungan ini di propinsi Riau, Sumatra.

\section{Dampak transmigrasi spontan}

Sejak pertengahan 1980-an, telah terjadi pertumbuhan besar dalam jumlah transmigran spontan dibandingkan dengan transmigran umum (Dick 1991:27-28). Nampaknya ada dua alasan yang mengakibatkan terjadinya hal ini. Pertama, perkembangan infrastruktur untuk program transmigrasi umum pada awal tahun 1980 -an telah menarik transmigran spontan. Kedua, pada tahun 1986 besarnya skala program transmigrasi umum dikurangi karena penurunan devisa dari minyak dan karena diputuskan untuk memusatkan dana yang terbatas pada peningkatan infrastruktur dan sistem produksi pada lokasi-lokasi transmigrasi yang telah ada (World Bank 1988:xxii-xxiii; Thiele 1994:191). Tomich dan van Noordwijk (1995:3-4) mengemukakan bahwa para transmigran spontan dengan cepat meniru sistem produksi karet penduduk asli di Sumatra.

Menurut Dick (1991:29) para transmigran spontan membuka lahan seluas kira-kira 4,25 ha per keluarga. Berdasarkan angka ini ia memperhitungkan bahwa sekarang transmigran spontan merupakan satu penyebab terpenting deforestasi, dan bertanggung jawab atas hilangnya tutupan hutan seluas 178.500 ha per tahun. Angka ini mungkin agak berlebihan mengingat - sama seperti halnya dengan transmigran umum - Dick meng-asumsikan bahwa semua lahan yang dibuka merupakan hutan, sedangkan mungkin kenyataannya tidaklah demikian.

Diantara pertanyaan-pertanyaan utama yang muncul dari informasi tersebut adalah: (1) Bagaimanakah pengalihan dari tanaman pangan ke tanaman perkebunan telah mengubah dampak transmigrasi pada tutupan hutan? (2) Apakah perubahan ini telah meningkatkan stabilitas dan matapencaharian penduduk? (3) Apabila demikian halnya, apakah ini kemudian menarik arus transmigran spontan yang lebih besar? (4) Apakah peningkatan jumlah transmigran merongrong budidaya perladangan berpindah tradisional, dan bagaimanakah hubungannya dengan masalah jual-beli lahan, hak atas tanah yang diakui secara formal dan hak milik secara adat?

\section{Kepadatan penduduk}

Fraser (1996) mengemukakan bahwa pertumbuhan kepadatan penduduk merupakan penjelasan fundamental akan masalah deforestasi di Indonesia. Data kepadatan penduduk tiap propinsi di Indonesia menunjukkan hubungan terbalik dengan data tutupan hutan (Tabel 3). Beberapa penulis telah melihat hubungan ini (FAO 1990:10; Barbier et al. 1993:7; Fraser 1996). ${ }^{18}$ Fraser $(1996: 6,15)$ menyatakan bahwa pada tiap 1\% kenaikan penduduk (kenaikan penduduk di pulaupulau di luar pulau Jawa adalah 3\%) terjadi penurunan kira-kira $0,3 \%$ tutupan hutan. Sebab itu keseluruhan penurunan luas tutupan hutan setiap tahun adalah $1 \%$, sesuai dengan pengamatan FAO yang memperlihatkan

\footnotetext{
17 Sebuah Penelitian pada tahun 1989 mengenai lima daerah pemukiman di Kalimantan Timur mendapatkan bahwa 23,6\% keluarga transmigran menjalankan sistem perladangan berpindah (Fasbender dan Erbe 1990:242-243).

18 Jepma dan Blom (1992:209) melaksanakan model yang menunjukkan pengaruh positif terhadap tutupan hutan akibat dari pengurangan laju pertumbuhan penduduk dari 1,6\% menjadi $1,0 \%$.
} 
Tabel 3: Kepadatan penduduk dan tutupan hutan pada tingkat propinsi di Indonesia (1982) (dari kurang padat ke yang lebih padat)

\begin{tabular}{|lcc|}
\hline Propinsi & $\begin{array}{c}\text { Kepadatan Penduduk } \\
\left(\text { orang } / \mathrm{km}^{2}\right)\end{array}$ & $\begin{array}{c}\text { Total Tutupan Hutan } \\
(\%)\end{array}$ \\
\hline Irian Jaya & 4 & 84 \\
Kalimantan Timur & 6 & 85 \\
Kalimantan Tengah & 7 & 73 \\
Kalimantan Barat & 18 & 59 \\
Sulawesi Tengah & 20 & 64 \\
Maluku & 22 & 81 \\
Riau & 25 & 62 \\
Sulawesi Tenggara & 27 & 65 \\
Jambi & 29 & 52 \\
Bengkulu & 42 & 57 \\
Sumatra Selatan & 45 & 33 \\
DI Aceh & 50 & 79 \\
Kalimantan Selatan & 58 & 49 \\
Sumatra Barat & 84 & 61 \\
Sulawesi Utara & 85 & 60 \\
Sulawesi Selatan & 101 & 46 \\
Sumatra Utara & 123 & 39 \\
Lampung & 145 & 18 \\
Jawa Timur & 632 & 23 \\
Jawa Barat & 680 & 17 \\
Jawa Tengah & 760 & 15 \\
\hline
\end{tabular}

Sumber: Fraser (1996:8)

bahwa besarnya tutupan hutan yang hilang setiap tahun mencapai 900.000 sampai 1 juta ha.

Tidak ada keraguan bahwa pertambahan penduduk di pedesaan Indonesia ikut memegang peranan dalam deforestasi. Namun masih harus dibuktikan bahwa kepadatan penduduk merupakan penyebab utama hilangnya tutupan hutan, seperti yang dinyatakan oleh Fraser (1966) dan penulis-penulis lain. Belum jelas seberapa jauh korelasi terbalik antara kepadatan penduduk dan tutupan hutan merupakan sebab akibat, dan seberapa jauh merupakan suatu kebetulan. Mungkin ada variabel-variabel selain yang digunakan oleh Fraser, yang menyebabkan korelasi yang tinggi ini. Beberapa orang penulis mencatat bahwa di Asia Tenggara - dan di daerah tropis lembab pada umumnya - ada urutan kegiatan yang khas dimana hutan mulamula dibuka oleh industri penebangan kayu (perusahaan $\mathrm{HPH}$ ), dan selanjutnya diusahakan untuk pertanian (Grainger 1993:70; Kummer dan Turner 1994).
Apabila demikian, maka mungkin dapat diargumentasikan bahwa di daerah-daerah dimana urutan kegiatan ini terjadi, kegiatan pembalakan oleh HPH merupakan "penyebab" deforestasi dan para peladang berpindah hanya mengisi "kekosongan" yang diciptakan oleh perusahaan-perusahaan HPH. Jalan pikiran ini membalikkan arah sebab akibat: pembukaan hutan menyebabkan peningkatan kepadatan penduduk di suatu daerah, bukan sebaliknya. ${ }^{19}$

Ada kelemahan lain dalam argumen Fraser yang bersifat neo-Malthus. Ada berbagai variabel independen (misalnya perubahan teknologi, distribusi kekayaan dan penghasilan, permintaan akan produk-produk pertanian, pertumbuhan infrastruktur, tingkat pendidikan wanita dan partisipasinya dalam pasar tenaga kerja, dll.), yang mengubah pengaruh variabel kependudukan pada tutupan hutan. Apabila variabel-variabel ini diperhitungkan, pengaruh pertumbuhan penduduk pada hilangnya tutupan hutan yang nampaknya men-

\footnotetext{
19 Ada beberapa faktor lain yang terlihat membalikkan siklus sebab akibat, termasuk hubungan yang erat antara industri penebangan (HPH) dan perladangan berpindah, akses yang disebabkan oleh jalan-jalan yang lebih baik, dan perpindahan penduduk ke garis batas hutan (forest frontier).
} 
dasar, menjadi tidak begitu jelas. Ada kemungkinan, misalnya, jumlah penduduk desa tetap atau berkurang (karena urbanisasi), sedangkan besarnya tutupan hutan yang hilang meningkat karena meningkatnya permintaan per kapita penduduk kota atau meningkatnya permintaan internasional akan produksi pertanian.

Tetapi keterangan non-Malthus juga ada kelemahannya. Angelsen (1995) memakai studi kasus dari Sumatra untuk mengemukakan pendapat yang berlawanan dengan pendapat Fraser (1996) - yakni bahwa bertambahnya jumlah penduduk belum tentu merupakan penyebab utama deforestasi. Ia membandingkan besarnya pengaruh faktor-faktor yang menyebabkan pembabatan hutan setiap tahun yakni: (1) perubahan proporsi rumahtangga yang membuka ladang bertanggung jawab atas $70 \%$ dari keseluruhan; (2) jumlah total rumahtangga bertanggung jawab atas $23 \%$ dari keseluruhan; dan ukuran rata-rata ladang bertanggung jawab atas 7\% dari keseluruhan (Angelsen 1995:1724). Analisa semacam ini memperlihatkan bahwa pertumbuhan jumlah penduduk menjelaskan kira-kira seperempat dari hilangnya tutupan hutan. Namun demikian, apakah mungkin, seperti dalam kasus analisa Fraser (1996), pandangan lain mengenai hubungan antar variabel-variabel yang relevan dapat menghasilkan kesimpulan yang berbeda? Mungkinkah, misalnya, kenaikan proporsi rumah tangga yang membuka ladang (dikatakan menjelaskan $70 \%$ fenomena hilangnya tutupan hutan) merupakan reaksi atas pertumbuhan dan kepadatan penduduk setempat? Menarik untuk dicatat bahwa dalam survai Angelsen (1995) tiga perempat dari responden petani percaya bahwa pertumbuhan penduduk mengakibatkan kekurangan lahan.

Penelitian lebih lanjut mengenai hubungan antara jumlah penduduk dan deforestasi tentunya akan bermanfaat, tetapi harus dilakukan dengan cara sedemikian rupa sehingga jelas dapat membedakan hubungan sebab akibat dan hubungan yang terjadi secara kebetulan, dengan jelas menerangkan semua arah sebab akibat yang penting, dan secara memadai menjelaskan bentuk-bentuk pelakunya. Mungkin langkah paling penting ke arah peningkatan kecanggihan analisa-analisa tersebut adalah dengan menanyakan apa saja yang menyebabkan pertumbuhan penduduk, kepadatan penduduk dan perpindahan penduduk (migrasi) - dengan kata lain, memperlakukan faktor kependudukan sebagai salah sebuah variabel antara (intervening variable), bukan sebagai variable bebas.

\section{KEGIATAN PEMBALAKAN DAN INDUSTRI PERKAYUAN}

Laju penebangan hutan di Indonesia rata-rata 40 juta kubik meter setahun, sedangkan laju penebangan yang "lestari berkelanjutan" (sustainable) yang direkomendasikan oleh Departemen Kehutanan adalah 22 juta kubik meter setahun (World Bank 1995:i). Menurut laporan hanya sebagian kecil pemegang konsesi yang melaksanakan penanaman pemerkayaan. Sebagian orang percaya bahwa perkembangan industri perkayuan dicapai dengan kerugian ekonomi dan lingkungan yang terlalu besar bagi Indonesia (Gillis 1988:181-2; Ahmad 1995) dan bahwa sumbangannya pada pembangunan ekonomi secara keseluruhan rendah (Hariadi 1993; Ahmad 1995).

Estimasi deforestasi yang disebabkan langsung oleh kegiatan pembalakan berkisar antara 77.000 ha sampai 120.000 ha setiap tahun (Tabel 2), yakni kirakira $10-20 \%$ dari keseluruhan kawasan yang telah hilang hutannya, dan $10-15 \%$ dari 800.000 ha yang ditebang setiap tahun. ${ }^{20}$ Dalam penelitian-penelitian tersebut diatas tidak diterangkan dalam pengertian bagaimana kegiatan pembalakan dianggap menyebabkan deforestasi. Tidak diketahui apakah penelitian-penelitian tersebut mengukur fenomena ini berdasarkan: (1) penebangan habis pada lahan-lahan yang dimaksudkan untuk tataguna non-hutan; ${ }^{21}$ (2) kawasan-kawasan yang pengelolaan silvikulturnya buruk, sehingga ditumbuhi alang-alang atau terkena kebakaran hutan; (3) kawasan-kawasan dimana konversi ke usaha pertanian tanpa sengaja dimudahkan dengan adanya kegiatan pembalakan dan dengan tidak diterapkannya perbatasan-perbatasan areal konsesi; atau gabungan dari hal-hal diatas. Meskipun penelitian-penelitian tersebut tidak menyebutkan informasi yang penting ini, tetapi menyiratkan bahwa pengelolaan konsesi yang tidak memadai dan cakrawala investasi jangka pendek di pihak pemegang konsesi memegang peranan penting dalam deforestasi bentuk ini.

Mengapa beberapa pemegang konsesi mengeskploitasi hutan dengan laju yang tidak mendukung kelestariannya, gagal mengelola konsesinya dengan baik, dan tidak memiliki pandangan ke arah investasi jangka panjang? Sebagian besar penjelasan para peneliti mengarah pada berbagai kebijakan pemerintah serta pelaksanaannya yang mereka pandang tidak memadai dan harus diperbaiki. Kekurangan-kekurangan ini dapat diklasifikasikan ke dalam tiga fenomena berikut.

\footnotetext{
${ }^{20}$ Flint (1994:1044) melihat bahwa untuk Asia Tenggara sebagai keseluruhan, pada periode 1880-1980 penebangan bertanggung jawab atas kira-kira $22 \%$ dari deforestasi.

21 Pemegang konsesi diizinkan menebang habis, dan dibebaskan dari peraturan tebang pilih, pada lahan-lahan hutan yang dimaksudkan untuk konversi.
} 
(1) Metode pembagian konsesi memberi pemegang konsesi lahan yang terlalu besar. Akibatnya pemegang konsesi tertentu kurang mempunyai insentif untuk mencegah perambahan oleh petani kecil, atau tidak mampu menghentikan perambahan yang demikian. Thiele (1994:187) mengatakan bahwa biaya konsesi (concession fees) yang rendah mendorong pemegang konsesi untuk menguasai areal yang luas sekali, "lebih untuk tujuan asuransi atau spekulasi daripada untuk memanen kayu". Ia menambahkan "ini bukan hanya menyiratkan bahwa sumberdaya milik rakyat dibiarkan menganggur, tetapi juga mendorong para peladang berpindah untuk melakukan deforestasi, karena para pemegang konsesi kurang mempunyai insentif untuk mengawasi perambahan apabila mereka memiliki kelebihan lahan”. Sebagai informasi tambahan, royalti konsesi hutan di Indonesia didasarkan pada volume kayu yang dihasilkan, bukan pada luasnya areal HPH, sehingga mendorong penguasaan areal konsesi yang kelewat luas.

(2) Kebijakan-kebijakan tertentu mendorong perilaku mencari rente ekonomi (rent-seeking behavior) dan akibatnya mengurangi insentif untuk pengelolaan jangka panjang. Besarnya pembayaran royalti kepada pemerintah rendah, yang berarti para pemegang konsesi dapat menikmati bagian yang besar dari potensi keuntungan areal konsesinya. Menurut Thiele (1994:190) "potensi tinggi untuk mendapatkan keuntungan yang lebih, mendorong kegiatan 'mencari rente ekonomi' (rent-seeking activities) dalam perolehan areal konsesi dan membuka jalan untuk korupsi, sehingga pelaksanaan persetujuan konsesi terancam untuk dilanggar. Gabungan antara royalti yang rendah dan batas masa konsesi 20 tahun mendorong "pembalakan kembali sebelum waktunya", dimana pemegang konsesi masuk kembali kedalam lokasi mereka setelah penebangan pertama (untuk melakukan penebangan yang kedua atau selanjutnya), sebelum HPH nya jatuh tempo, sehingga merusak tegakan-tegakan yang belum siap panen. ${ }^{22}$ Ascher (1993:2) mengatakan bahwa rendahnya rente yang ditarik oleh pemerintah ini (rent capture) mendorong pengelolaan yang buruk, bukan hanya karena sumberdaya hutan dinilai lebih rendah dari yang semestinya, tetapi juga karena para pemegang konsesi tergesa-gesa memanen kayunya karena takut royalti yang rendah saat ini akan dinaikkan. Pada tahun 1990 survai-survai menemukan bahwa di areal konsesi di mana telah dilakukan pembalakan, tegakan tinggal yang rusak mencapai $40 \%$, sehingga sangat menurunkan nilainya dan mengurangi insentif untuk melindunginya dari perambahan dan kebakaran hutan (World Bank 1990:xxi). Royalti yang rendah dan pajak ekspor yang tinggi yang dikenakan pada kayu gelondongan dan produk-produk kayu dari Indonesia menekan harga domestik, sehingga membatasi minat peremajaan/penanaman kembali (World Bank 1995:ii, 8). ${ }^{23}$ Ascher (1993:4) mengatakan bahwa ada pertimbangan-pertimbangan lain selain pertimbangan yang menyangkut kualitas pengelolaan konsesi, yang masuk dalam proses perpanjangan ijin $\mathrm{HPH}$, sehingga tidak mendorong kinerja yang baik.

(3) Kurangnya dukungan untuk perlindungan hutan di tingkat propinsi. Pemerintah daerah tingkat propinsi menerima sebagian kecil dari royalti pengusahaan hutan yang dikutip oleh pemerintah, yang seperti telah dikemukakan diatas, sudah cukup rendah. World Bank (1995:19) menerangkan bahwa "pemerintah daerah tingkat propinsi dengan tutupan hutan yang luas mungkin terdorong untuk mengubah hutannya menjadi bentuk tataguna lahan lain, yang menghasilkan pemasukan daerah yang lebih besar, atau yang paling sedikit dapat merupakan sumber penghasilan bagi masyarakat yang tinggal di sekitar hutan, supaya mereka tidak menjadi beban bagi sumberdaya propinsi tersebut". Masalah yang lain lagi adalah tertumpuknya pegawai kehutanan di Pulau Jawa, padahal sumberdaya hutan jauh lebih banyak terdapat di luar Jawa. ${ }^{24}$

Para komentator mengenai situasi hutan di Indonesia mengatakan bahwa pengelolaan konsesi/HPH dapat ditingkatkan dengan pembaharuan kebijakan sebagai berikut:

- menaikkan royalti dan penerimaan pemerintah (rent capture) secara menyolok (Gray dan Hadi 1990; World Bank 1990:xx; Ascher 1993; D’Silva dan Appanah 1993; Ramli dan Ahmad 1993; Thiele 1994; Ahmad 1995; World Bank 1995);

- memperpanjang siklus HPH dan meningkatkan jaminan hak pengelolaan hutan bagi para pemegang HPH (World Bank 1990:xx; D'Silva dan Appanah 1993; Thiele 1994, 1995; World Bank 1994, 1995; Kartodihardjo 1995);

- memperbesar persaingan dalam perolehan HPH (Gray dan Hadi 1990; Thiele 1994);

- memperbesar perhitungan biaya HPH (concession fees) yang dikenakan berdasarkan luas areal, dan bukan berdasarkan volume hasil (Gray dan Hadi 1990; Thiele 1994), serta tindakan-tindakan lain.

\footnotetext{
22 Perlu dicatat bahwa pemerintah Indonesia sedang mempertimbangkan perpanjangan masa konsesi menjadi 70 tahun.

23 Harga kayu gelondong pada tahun 1995 hanyalah 25-30\% harga internasional (World Bank 1995:ii).

24 Pada tahun 1990 limapuluh persen dari staf Departemen Kehutanan berada di Jawa, meskipun pulau Jawa hanya memiliki 2\% dari seluruh lahan hutan di negeri ini (World Bank 1990:xxi).
} 
Dikatakan bahwa perubahan-perubahan kebijakan di atas dapat mendorong perbaikan pengelolaan hutan produksi, serta menghasilkan pemasukan yang besar bagi pemerintah, yang sebagian dapat dipakai untuk meningkatkan pelaksanaan undang-undang kehutanan.

Kalau ini masalahnya, mengapa tidak ada keinginan yang lebih kuat pada pemerintah untuk melaksanakan pembaharuan kebijakan-kebijakan tersebut? Ascher (1993), Dauvergne (1994), King (1996) dan Ross (1996) menyatakan bahwa jawaban pertanyaan tersebut bersifat politis. Ascher (1993) berpendapat bahwa Pemerintah dan Departemen Kehutanan memandang hutan sebagai aset untuk dilikuidasi dalam rangka diversifikasi ekonomi; penerimaan pemerintah (rent capture) dijaga tetap rendah untuk memudahkan proses ini. Dauvergne juga berpendapat serupa (1995: 503-507) yakni bahwa deforestasi secara fundamental berakar pada struktur dan proses politik Indonesia, dan pembuat-pembuat kebijakan "memandang hutan sebagai sumberdaya yang berharga, tetapi dapat dikorbankan, dan berguna untuk mendapatkan devisa guna membiayai industrialisasi”. Ross (1996) mengatakan bahwa pada banyak negara berkembang, termasuk Indonesia, konsesi hutan diberikan kepada orang-orang berpengaruh di dalam "koalisi penguasa" sebagai suatu bentuk dukungan politis. Ditambahkannya bahwa "industri-industri perkayuan di negara-negara berkembang hampir selalu berada di tangan sekutu koalisi yang berkuasa; sehingga pemerintah segan bertindak melawan kepentingan industri-industri tersebut" (Ross 1996:170). King (1996:216) melihat perbaikan pengelolaan sektor kehutanan dihalangi oleh sifat-sifat pemerintahan yang patrimonial, dan bahwa pembaharuan yang berarti baru akan terlaksana apabila terjadi "penggantian rejim, suplai kayu yang kritis, atau ancaman dari luar terhadap ekspor produk hutan Indonesia".

Meskipun mungkin ada secercah kebenaran dalam penjelasan-penjelasan di atas, uraian tersebut tidak menjawab secara memuaskan mengapa ada pemegang konsesi/HPH yang mematuhi undang-undang/ peraturan-peraturan kehutanan, mengelola konsesinya dengan baik dan melaksanakan peremajaan/penanaman kembali. Studi perbandingan mengenai para pemegang konsesi akan sangat bermanfaat dalam upaya lebih memahami peranan kegiatan pembalakan dan industri perkayuan dalam perubahan tutupan hutan di Indonesia.

Hal lain yang perlu diteliti adalah implikasi pengelolaan hutan pada investasi multi-sektor. Apakah konsekuensi praktis dari kenyataan bahwa beberapa pemegang HPH yang besar mempunyai investasi bukan hanya di bidang kehutanan, tetapi juga di sektor ekonomi yang lain? Apakah mungkin eksploitasi kayu merupakan "modal awal"("seed capital") bagi industriindustri lain, sehingga mengurangi insentif untuk konservasi jangka panjang? Sebaliknya, apakah mungkin investasi dalam bidang kehutanan merupakan suplemen penting bagi investasi-investasi lain di luar sektor ini, sehingga mengharuskan beberapa pemegang HPH tertentu untuk mempertahankan kelestarian hutan?

\section{PERKEBUNAN BESAR DAN HUTAN TANAMAN INDUSTRI}

Ada ketidakcocokan yang cukup besar dalam estimasiestimasi deforestasi yang diakibatkan oleh pertumbuhan perkebunan-perkebunan besar dan hutan tanaman industri (lihat Tabel 2). Estimasi-estimasi tersebut berkisar dari angka yang rendah, yaitu $11.400 \mathrm{ha} /$ tahun sampai 274.000 ha/tahun. ${ }^{25}$ Tidak jelas apakah istilah "perkebunan besar" terbatas pada tanaman komersial di perkebunan besar, atau apakah itu juga menyangkut hutan tanaman industri.

\section{Tanaman komersial di perkebunan besar}

Dalam sepuluh tahun terakhir ini telah terjadi pertumbuhan yang besar dalam luas lahan yang dimanfaatkan untuk produksi tanaman komersial di Indonesia. Subsektor tanaman komersial secara relatif belum berkembang pada awal pemerintahan Suharto, tetapi telah dipromosikan secara aktif sejak awal tahun 1980-an dalam hubungannya dengan mandat untuk mengembangkan pemasukan devisa non-minyak (Economist Intelligence Unit 1995a:27). Kalau sub-sektor tanaman pangan hampir seluruhnya terdiri atas petani kecil/rakyat, sub-sektor tanaman komersial terdiri atas petani rakyat, perkebunan besar komersial milik swasta dan perkebunan-perkebunan negara (Economist Intelligence Unit 1995a:27).

Kelapa sawit Afrika patut mendapatkan perhatian khusus dalam konteks perubahan tataguna lahan, karena laju pertumbuhannya yang mencolok. Pada tahun 1994 terdapat 1,2 juta ha; tanaman kelapa sawit yang diusahakan oleh perkebunan besar swasta dan perkebunan negara - ini merupakan jenis tanaman perkebunan besar terluas di Indonesia (PDP 1996:55-56). Areal kelapa sawit di perkebunan-perkebunan besar telah tumbuh duabelas kali lipat, dari 106.000 ha pada tahun 1967 menjadi kira-kira 1,3 juta ha pada tahun 1995 (DJP 1995:4). ${ }^{26}$ Produksi kelapa sawit meningkat

\footnotetext{
25 Estimasi rendah berasal dari TAG (1991) dan Dick (1991), dan estimasi tinggi berasal dari FAO (1991) sebagaimana disitir oleh World Bank (1994:52).

${ }^{26}$ Kalau petani rakyat ikut dihitung, total areal kelapa sawit menjadi kira-kira 2 juta ha pada tahun 1996 (DJP 1995:4). Proyeksi pembagiannya untuk tahun 1995 adalah: petani rakyat (656.099 ha atau 33,6\%); perkebunan negara (390.355 ha atau 20,0\%); dan perkebunan besar swasta (905.166 ha atau 46,38\%) (DJP 1995).
} 
lebih dari sepuluh kali lipat dari 397.000 ton pada tahun 1975 menjadi lebih dari 4 juta ton pada tahun 1994 (Larson 1996:32). Indonesia merupakan salah satu produsen minyak goreng dengan biaya produksi terendah di dunia, sehingga memotivasi investasi baru dalam usaha kelapa sawit (Larson 1996:1).

Sedikit sekali informasi yang tersedia mengenai berapa banyak perluasan areal perkebunan besar dilakukan dengan mengorbankan tutupan hutan. Studi oleh Osgood (1994) menyatakan bahwa ada hubungan statistik antara pertumbuhan perkebunan besar dan deforestasi di Indonesia, tetapi informasi yang lebih spesifik hampir tidak ada. Pada tahun 1990 World Bank (1990:34) mengatakan perkembangan tanaman perkebunan besar mengkonsumsi areal hutan primer yang relatif sedikit dibandingkan dengan transmigrasi, ${ }^{27}$ tetapi mencatat sulitnya mencari lahan yang tidak berhutan untuk mendirikan perkebunan besar yang baru, serta mencatat cepatnya peningkatan permintaan untuk mengkonversi lahan menjadi perkebunan besar. Pada saat itu pemerintah meluncurkan program PIR, pemberian kredit untuk pembangunan perkebunan-perkebunan swasta dimana $40 \%$ dari lahan yang ditanami menjadi milik perkebunan besar dan $60 \%$ untuk petani rakyat. Sepanjang REPELITA III dan separuh dari REPELITA IV (kira-kira 1979-1987), pada lahan yang dimaksudkan untuk konversi telah dialokasikan lahan seluas 864.000 ha untuk tujuan tersebut, yang tidak semuanya berhutan (World Bank 1995:35). Data-data ini sulit dihubungkan dengan pernyataan Hill (1994:204) bahwa kebanyakan peningkatan produksi dari perkebunan besar swasta sejak awal 1980-an terjadi berkat pemakaian teknologi baru, dan bukannya akibat perluasan areal yang dipakai; ditambahkannya bahwa hanya dalam kasus kelapa sawit terjadi perkembangan besar dalam luas areal yang ditanami.

Pemerintah memperkirakan di luar Jawa tersedia 40 juta ha lahan untuk dikonversikan menjadi budidaya tanaman komersial (Economist Intelligence Unit 1995a:27). Ini merupakan pertanda yang kuat bahwa akan ada tekanan tambahan untuk mengkonversi hutan menjadi tataguna lahan dalam bentuk ini. Pemerintah sedang membuka kawasan seluas 1,2 juta ha di Kalimantan Tengah untuk produksi padi dan tanaman lain dalam skala besar (McBeth 1995), dan sudah ada rencana perluasan perkebunan besar, terutama perkebunan kelapa sawit, dalam jumlah besar.

\section{Hutan tanaman industri}

Berawal dari akhir tahun 1980-an telah ada rencanarencana besar untuk memperluas areal hutan tanaman industri. Sampai dengan Desember 1995 luas hutan tanaman industri yang telah dibangun hanya 520.000 ha. ${ }^{28}$ Pemerintah mencanangkan target agar sampai tahun 1990 telah dibangun hutan tanaman industri seluas 1,4 juta ha, sampai tahun 19951,8 juta ha, sampai tahun 2000 2,3 juta ha dan sampai tahun 2030 10,5 juta ha (World Bank 1995:8). Sasaran jangka pendek adalah untuk mensuplai industri pulp (bubur kertas) dan kertas yang mulai berkembang dan akhirnya untuk memenuhi sebagian kebutuhan industri produk perkayuan (hal. 8). Pabrik-pabrik pulp dan kertas saat ini mengandalkan hutan alam, tetapi letak hutan alam makin lama semakin jauh dari jangkauan pabrik (hal. 8). Kemajuan ke arah pengembangan hutan tanaman industri (HTI) untuk pulp dan kertas akan dipengaruhi oleh kinerja industri ini dan oleh harga produk-produknya yang terkenal sangat berfluktuasi. Diperkirakan bahwa areal HTI seluas 2 juta ha dapat mensuplai seluruh kebutuhan kayu untuk pembuatan pulp (bubur kertas) sampai dengan tahun 2020. Pengembangan HTI untuk suplai kayu bulat tertahan karena harga kayu gelondongan yang rendah; hanya HTI pada lokasi-lokasi yang paling produktif yang akan menguntungkan (hal. 8). Hutan tanaman industri telah menjadi tonggak baru bagi pembangunan transmigrasi. Para transmigran akan dimukimkan kembali untuk bekerja di HTI atau di pabrik-pabrik pulp dan kertas.

WALHI (1992:2-3) serta Belcher dan Gennino (1993:15) menunjukkan bahwa pembangunan HTI, meskipun dilaporkan dimaksudkan untuk melindungi hutan alam, mungkin sebenarnya malahan ikut berperan dalam perusakan hutan alam. Mereka telah mengangkat hal yang penting. Pabrik-pabrik pulp dan kertas (serta industri produk kayu yang lain) dibangun dengan harapan bahwa bahan mentahnya akan disuplai oleh HTI. ${ }^{29}$ Tetapi, apabila suplai dari HTI ini tidak tersedia segera, tekanan pada hutan alam mungkin akan meningkat. Akan cukup bermanfaat untuk meneliti apakah pertumbuhan industri pulp dan kertas, serta industri-industri pengolahan kayu lain, dalam kenyataannya meningkatkan eksploitasi hutan alam, atau apakah mereka justru meletakkan dasar ke arah produksi yang lestari berbasiskan hutan tanaman industri.

\footnotetext{
27 Dilaporkan bahwa 46.000 ha lahan hutan dibuka untuk sektor perkebunan besar selama REPELITA III (1979-1984) (World Bank 1990:34).

${ }^{28}$ Laporan dari Direktorat Pengawasan Pengelolaan Hutan, DepHut, sebagaimana dilaporkan di Jakarta Post, 9 April 1996.

29 Porter (1994:434) menyebutkan adanya bahaya bahwa pabrik pulp dan kertas di Indonesia akan mengkonsumsi areal hutan yang luas.
} 


\section{PEDOMAN UNTUK MENENTUKAN LAJU DAN PENYEBAB DEFORESTASI}

Pada bagian sebelumnya kita telah melihat bahwa usaha-usaha untuk mendapatkan laju perubahan dan penyebab deforestasi telah terhalang oleh:

- Definisi yang tidak dinyatakan, tidak jelas atau tidak konsisten dalam hal istilah-istilah dan konsepkonsep kunci seperti "hutan", "deforestasi" dan pelaku perubahan tutupan hutan.

- Tidak adanya atau kurangnya data dasar dan data rentang waktu (time series) perubahan tutupan hutan.

- Kurangnya pengetahuan dasar mengenai ciri-ciri sosial para pelaku perubahan tutupan hutan.

- Pemikiran yang salah dan tendensius serta interpretasi informasi secara selektif, yang diakibatkan oleh kurang jelasnya pemakaian istilah-istilah dan konsep-konsep kunci dan tidak adanya atau kurangnya data.

Kami menyarankan agar usaha-usaha untuk menentukan laju dan penyebab perubahan tutupan hutan di masa mendatang didasarkan pada pedoman berikut:

\section{Laju perubahan tutupan hutan}

Laju perubahan tutupan hutan seharusnya didasarkan pada perbandingan gambar-gambar satelit atas liputan lahan (land cover) pada dua (atau lebih) waktu yang berbeda. ${ }^{30}$ Metode penciptaan gambar harus sama, untuk menghindari interpretasi yang salah dari perbedaan ketajaman, tekstur atau warna sebagai perubahan tutupan hutan. Idealnya, gambar-gambar yang diambil pada waktu yang lalu cukup tua agar perbedaan tutupan hutannya dapat dilihat dengan jelas, dan gambar-gambar yang baru cukup mutakhir sehingga pengukuran perubahannya menangkap fenomena baru yang relevan.

Definisi-definisi istilah-istilah kunci harus jelas dan dipakai secara konsisten untuk segala aspek pengukuran laju perubahan tutupan hutan. Kami rekomendasikan pemakaian definisi "hutan" dan "deforestasi" yang dipakai oleh FAO (1996) dalam publikasinya Forest Resources Assessment 1990: Survey of Tropical
Forest Cover and Study of Change Processes. ${ }^{31}$ "Hutan" dijabarkan sebagai "hutan alam" (baik hutan yang luas atau yang terfragmentasi/terpotong-potong); "non-hutan" merujuk pada "lahan-lahan lain yang berhutan (wooded lands)" (termasuk semak belukar dan lahan dalam masa bera pendek); dan "vegetasi berkayu buatan manusia" mencakup perkebunan (termasuk hutan tananam industri maupun perkebunan tanaman keras) (hal. 20).

Studi ini memakai tiga tingkatan definisi "hutan" dan "perubahan tutupan hutan" sesuai dengan berbagai tujuan para peneliti. "Hutan" dijabarkan sebagai: "hutan tertutup"; "hutan tertutup + terbuka $+2 / 3$ terpotong-potong/terfragmentasi"; atau "hutan tertutup + terbuka + terpotong-potong/terfragmentasi + lahan dalam masa bera yang panjang" (hal. 20). "Perubahan tutupan hutan" didefinisikan sebagai berikut (hal. 22):

- Deforestasi kotor (gross deforestation) dihitung sebagai "jumlah seluruh areal transisi dari kategorikategori hutan alam (utuh dan terpotong-potong) ke semua kategori-kategori lain".

- Deforestasi neto dihitung sebagai "luas areal deforestasi kotor dikurangi seluruh areal transisi dari semua kategori-kategori lain ke kategorikategori hutan alam".

- Degradasi neto hutan alam dihitung dari areal transisi dalam kategori-kategori hutan alam, dengan menjumlahkan semua perubahan yang berhubungan dengan degradasi dikurangi semua perubahan yang berhubungan dengan perbaikan kondisi hutan (amelioration). ${ }^{32}$

Kami sarankan konsultasi terus-menerus mengenai metodologi dan spesifikasi teknis dalam studi FAO, baik karena kedua hal tersebut merupakan perbaikan yang berarti atas praktek-praktek masa lalu, maupun karena metodologi yang seragam memungkinkan dilakukannya perbandingan kecenderungan lintas daerah dan lintas negara.

Akhirnya kami sarankan agar analisa tingkat dan laju perubahan tutupan hutan memberikan perhatian yang proporsional pada permasalahan degradasi. Studi-studi terdahulu cenderung menekankan deforestasi dengan mengesampingkan degradasi. Kecenderungan ini mengabaikan kenyataan bahwa degradasi (dimana industri perkayuan memegang peranan penting)

\footnotetext{
30 Untuk informasi mengenai perkembangan metodologi dalam penaksiran perubahan tutupan hutan, lihat terutama Downton (1995) dan FAO (1996).

31 Ada berbagai definisi untuk "hutan" dan "deforestasi" yang muncul dalam publikasi-publikasi FAO selama ini (lihat diskusi mengenai hal ini dalam UNESC 1996:6-7).

32 Degradasi didefinisikan sebagai "turunnya kelebatan atau meningkatnya gangguan dalam kelas-kelas hutan" dan perbaikan kondisi hutan (amelioration) didefinisikan sebagai "peningkatan kelebatan atau turunnya gangguan dalam kelas-kelas hutan" (FAO 1996:21).
} 
sering merintis jalan ke arah deforestasi (didefinisikan sebagai hilangnya tutupan hutan secara permanen) oleh pelaku-pelaku lain.

\section{Penyebab perubahan tutupan hutan}

Penentuan penyebab perubahan tutupan hutan menghadapi tantangan besar dalam konsep dan metodologinya. Memastikan penyebab tidak mudah karena menyangkut pembuktian pola-pola keterkaitan antara sebab akibat sepanjang waktu, dan seringkali data-data tidak mencukupi untuk membuktikan keterkaitannya. Seperti telah kita lihat diatas, beberapa jenis pelaku mungkin beroperasi di lokasi yang sama, sehingga sulit memisahkan pengaruh pelaku yang satu dari yang lain. Kami sarankan pedoman-pedoman berikut untuk perbaikan penentuan penyebab perubahan tutupan hutan.

\section{Tingkatan penyebab}

Penyebab harus diklasifikasi dalam tiga tingkatan penjelasan yakni: pelaku; penyebab langsung; dan penyebab yang mendasari perubahan tutupan hutan (underlying cause). ${ }^{33}$ Pelaku merujuk pada orangorang atau organisasi (misalnya petani rakyat, perusahaan HPH, perkebunan atau HTI) yang mempunyai peranan fisik dan/atau peranan membuat keputusan langsung dalam perubahan tutupan hutan. Penyebab langsung perubahan tutupan hutan adalah parameter-parameter keputusan yang mempunyai pengaruh langsung pada perilaku para pelaku. Contohcontoh parameter-parameter yang dimaksud adalah: harga-harga relatif; akses relatif ke sumberdaya dan pasar; ketersediaan teknologi; peraturan-peraturan mengenai penggunaan sumberdaya; dan tradisi kebudayaan. Penyebab yang mendasari perubahan tutupan hutan mencakup kekuatan-kekuatan nasional, regional, atau internasional yang dapat mengatur pengaruh parameter-parameter keputusan. Contohcontoh kekuatan-kekuatan demikian adalah struktur sosial, hubungan kekuasaan, pola akumulasi modal, ketentuan-ketentuan perdagangan, dan perubahanperubahan demografis dan teknologi. Perhatikan pada Tabel 1 bahwa penilaian lama mengenai penyebab perubahan tutupan hutan terfokus pada pelaku, sedangkan formulasi baru memberikan perhatian pada pelaku dan penyebab-penyebab yang mendasari perubahan tersebut.

\section{Interaksi antar pelaku atau kemandirian pelaku}

Seperti telah disebutkan sebelumnya, ada kemungkinan berbagai jenis pelaku beroperasi pada lokasi yang sama. Juga bisa terjadi para pelaku beroperasi pada lokasi yang terpisah dan hampir tidak mempunyai hubungan satu sama lain. Dalam mencari penyebab perubahan tutupan hutan, menentukan bentuk-bentuk interaksi atau kemandirian ini merupakan hal yang penting.

Dalam kasus-kasus dimana beberapa pelaku yang berbeda beroperasi pada lokasi yang sama, besar kemungkinan interaksi antar pelaku menimbulkan akibat-akibat penting yang bisa meningkatkan atau menurunkan perubahan tutupan hutan. Perubahan yang meningkat dapat terjadi dalam kasus dimana kompetisi untuk memperoleh akses terhadap lahan menaikkan nilai hasil lahan (land rent) dan melemahkan hak adat atas tanah, seperti yang telah terjadi di propinsi Riau, Sumatra (Angelsen 1995:1722-1724). Perubahan yang menurun mungkin terjadi dalam kasus-kasus dimana (misalnya) para peladang berpindah berhasil melindungi hutan adat mereka dari perambahan oleh para pemegang $\mathrm{HPH}^{34}$ Sebaliknya, dalam kasus-kasus dimana para pelaku beroperasi sendiri-sendiri, terpisah satu sama lain, mungkin ada faktor-faktor yang memudahkan atau menghalangi terjadinya perubahan tutupan hutan. Misalnya, mungkin ada penghuni hutan yang lahannya terlindung dengan relatif baik dari kegiatan perambahan, karena mereka tinggal di hutan primer yang terpencil di daerah perbukitan yang relatif tidak dapat dijangkau oleh perusahaan-perusahaan HPH.

Sedikit sekali yang diketahui mengenai penyebaran para pelaku secara geografis dan akibat-akibat interaktif (atau sinerjis) mereka pada perubahan tutupan hutan. Informasi mengenai hal ini hanya samar-samar dan mungkin sudah ketinggalan zaman. Weinstock dan Sunito (1989:50) mengatakan bahwa 39,8\% dari perladangan berpindah terjadi "pada lahan-lahan yang menjadi perhatian serius pengelola hutan produksi". Sutter (1989:13) memperkirakan 85\% dari deforestasi setiap tahun terjadi pada hutan-hutan konversi dan produksi (tetapi pelakunya tidak disebutkan). Data World Bank (1990:6) menunjukkan bahwa besarnya kanopi hutan yang terbuka lebih luas di kawasan hutan produksi (baik "hutan produksi terbatas" maupun "hutan produksi biasa") dibandingkan dengan luas kanopi hutan yang terbuka di kawasan cagar alam dan hutan lindung, tetapi lagi-lagi informasinya tidak cukup untuk mengetahui penyebabnya. Pemahaman yang lebih baik mengenai akibat-akibat dari hal-hal tersebut diatas akan bermanfaat, khususnya dengan adanya kompetisi yang meningkat untuk memperoleh akses terhadap lahan di pulau-pulau di luar Jawa, dan semakin besarnya peranan perkebunan besar dan HTI dalam perubahan tutupan hutan.

\footnotetext{
33 Formulasi ini menggabungkan pikiran-pikiran yang disarankan oleh Arild Angelsen dan David Kaimowitz.

34 Komunikasi pribadi dengan Kevin Jeanes, Pimpinan Team, Proyek Konservasi Suaka Margasatwa Danau Sentarum, Kalimantan Barat, Oktober 1996.
} 


\section{Pemanfaatan gambar-gambar satelit/GIS (Sistem Informasi Geografis)}

Dalam hal-hal tertentu, gambar-gambar satelit dan pemetaan dengan GIS dapat membantu menentukan pola penyebab perubahan tutupan hutan. Misalnya, gambar-gambar dengan ketajaman tinggi (disertai pencocokan fakta di lokasi/ground truthing) dapat merekam perubahan dari tutupan hutan alam menjadi perkebunan monokultur kelapa sawit. Dalam hal ini "penyebabnya" (didefinisikan disini sebagai bentuk akhir tataguna lahan non-hutan) sudah jelas. Tetapi ada banyak kasus dimana perubahan dari hutan alam tertutup menjadi hutan yang terpotong-potong/terfragmentasi memberikan hanya sedikit informasi visual mengenai penyebabnya, meskipun gambar-gambarnya memiliki ketajaman tinggi. Dalam hal ini, diperlukan penelitian ilmu sosial untuk mencapai pemahaman penuh atas penyebab perubahan tutupan hutan. Dalam melaksanakan penelitian mengenai penyebabnya, perlu diketahui kemampuan dan keterbatasan gambargambar dan teknologi GIS.

\section{Penyebab yang berhubungan dengan ekonomi makro}

Indonesia saat ini dikenal akan kestabilan dan ketangguhan situasi ekonominya. Kebijakan-kebijakan restrukturisasi ekonomi makro telah diterapkan sejak tahun 1970-an sebagai tanggapan atas kejutan minyak bumi di seluruh dunia yang mempengaruhi ekonominya secara dramatis, dan masih terasa akibatnya sampai sekarang. Indonesia dipandang sebagai kasus keberhasilan penyesuaian ekonomi makro, karena dengan kebijakan deregulasi menyeluruh, diversifikasi ekspor serta devaluasi mata uang rupiah, dapat mempertahankan laju pertumbuhan ekonomi yang tinggi. Tidak diketahui apakah pengaruh keseluruhan kebijakan di atas - positif atau negatif - terhadap tutupan hutan di negara ini. Kebijakan penyesuaian ekonomi makro tersebut dan kondisi-kondisi ekonomi makro yang lain (harga-harga komoditas pokok, besarnya hutang luar negeri, ketentuan-ketentuan perdagangan dalam sektor pertanian, dan sektor pedesaan) belum dipelajari secara memadai dalam hubungannya dengan kehidupan masyarakat di sekitar dan di dalam hutan dan dalam hubungannya dengan keadaan hutan. ${ }^{35}$ Model-model yang dibuat oleh Jepma dan Blom (1992) dan Thiele (1995) merupakan terobosan yang menarik untuk topik ini. Penelitian di masa mendatang harus mempelajari akibat menyeluruh dari berbagai kondisi ekonomi makro pada tutupan hutan, melalui dampaknya terhadap para petani rakyat (pilihan pola migrasi dan usaha tani), petani kaya (keputusan-keputusan investasi di garis batas hutan atau "forest frontier") dan para pemegang HPH (insentif untuk mengelola hutan primer dalam jangka panjang).

\section{RINGKASAN DAN KESIMPULAN}

Sampai tingkat tertentu deforestasi di Indonesia memang diperlukan untuk memenuhi kebutuhan akan produksi pangan yang meningkat dan untuk kegiatankegiatan lain yang berhubungan dengan perkembangan ekonomi. Pemerintah Indonesia telah menetapkan hutan konversi (kira-kira seperempat dari keseluruhan lahan hutan) sebagai kawasan-kawasan yang tepat untuk deforestasi. Namun demikian, deforestasi dan degradasi hutan telah beranjak lebih jauh dari perbatasan hutan-hutan konversi, dan telah ada masalah-masalah yang patut dicatat mengenai penentuan tataguna lahan yang kurang sesuai. Studi RePPProT (1990:36), misalnya, menemukan bahwa 30,8 juta ha hutan produksi harus diklasifikasi ulang sebagai hutan lindung.

Agar dapat mengatasi masalah yang terjadi akibat hilangnya tutupan hutan yang tidak seharusnya di Indonesia, perlu diketahui laju perubahan tutupan hutan dan penyebabnya. Keraguan dan kerancuan fundamental mengenai laju dan penyebab deforestasi di Indonesia harus diselesaikan. Pemahaman situasi secara lebih baik merupakan prasyarat untuk merancang kebijakan-kebijakan baru dan menyesuaikan kebijakan-kebijakan yang ada dengan tujuan meningkatkan kesejahteraan masyarakat di sekitar dan di dalam hutan dan konservasi serta pengelolaan hutan-hutan di Indonesia.

Untuk mencapai hal itu, pertanyaan-pertanyaan utama yang harus dijawab adalah:

(1) Bagaimanakah kita akan mendefinisikan "hutan", "deforestasi" dan "pelaku" dalam konteks Indonesia? Ini merupakan langkah mendasar bukan hanya untuk menafsirkan informasi yang ada, dan membangun basis teori yang meyakinkan untuk pelaksanaan penelitian selanjutnya, tetapi juga untuk menerapkan "bahasa yang sama" diantara para peneliti dan pembuat kebijakan. Kami menyarankan agar para peneliti memakai istilah dan metodologi yang diusulkan oleh FAO (1996) dalam menghadapi masalah ini.

(2) Apakah ciri-ciri sosio-ekonomi dan praktek-praktek tataguna lahan berbagai pelaku yang dikelompokkan menjadi satu dalam istilah "perladangan berpindah"? Pertanyaan yang terkait adalah: Bagaimanakah proporsi berbagai jenis petani rakyat yang berladang di hutan atau di pinggir hutan (misalnya peladang berpindah, perambah hutan, dan petani yang mengusahakan

\footnotetext{
35 Diantara pustaka yang membahas efek kondisi ekonomi makro pada komoditas pertanian tertentu, lihat: Barlow dan Muharminto (1982:88, 112); Nancy (1988); Siebert et al. (1994); Angelsen (1995).
} 
perkebunan rakyat)? Secara geografis, dimanakah para petani rakyat biasanya melakukan usaha pertaniannya? Apakah hubungan antara tingkat penghidupan (misalnya pemenuhan kebutuhan hidup yang pokok vs. pencarian tambahan pemasukan) dengan konservasi hutan?

(3) Apakah hubungan antara kenaikan kepadatan penduduk dan hilangnya tutupan hutan bersifat kausal atau hanya kebetulan? Jawaban atas pertanyaan ini banyak mengandung hal-hal praktis, dengan pengertian bahwa keputusan-keputusan akan terus dibuat mengenai di mana transmigran akan ditempatkan dan di mana tidak akan ditempatkan, di mana pemukiman pada umumnya akan diizinkan dan di mana tidak akan diijinkan. Penafsiran yang berguna bagi korelasi terbalik antara kepadatan penduduk dan tutupan hutan harus didasarkan pada konseptualisasi yang jelas dan konsisten atas para pelaku deforestasi, pengakuan bahwa kependudukan merupakan variabel antara (intermediate variable), dan penerimaan atas semua variable bebas yang relevan.

(4) Mengapa ada pemegang konsesi (HPH) yang dilaporkan mengelola konsesinya dengan baik, sedangkan yang lain tidak? Pertanyaan-pertanyaan yang berhubungan adalah: Sejauh mana pembaharuanpembaharuan kebijakan yang diusulkan (peningkatan penerimaan pemerintah atas hutan yang telah diberikan ijin eksploitasinya atau 'rent capture', perpanjangan siklus konsesi dan jaminan hak pengelolaan hutan, bertambahnya kompetisi untuk memperoleh HPH, kenaikan biaya konsesi berdasarkan luas areal) akan meningkatkan kinerja pengelolaan konsesi hutan? Apakah kepentingan negara dalam hubungannya dengan konservasi jangka panjang dan pengelolaan hutan primer?

(5) Apakah dampak keseluruhan restrukturisasi ekonomi makro dan perubahan harga-harga komoditas sejak awal 1980-an terhadap tutupan hutan? Jawabanjawaban pertanyaan ini dan pertanyaan-pertanyaan lain pada tingkat ekonomi makro akan mempunyai nilai praktis yang tinggi untuk merancang pembaharuan-pembaharuan dalam kebijakan-kebijakan sektoral maupun ekstra-sektoral.

Selain menjawab pertanyaan-pertanyaan ini, penelitian lebih lanjut mengenai tingkat dan penyebab deforestasi di Indonesia, harus memperhatikan dua pegangan yang muncul dari ulasan analisa-analisa yang telah dikerjakan sampai saat ini (lihat Tabel 1). Pertama, harus diakui bahwa beberapa jenis pelaku mempunyai peran penting dalam proses konversi hutan. Oleh sebab itu para peneliti tidak boleh mengikuti kecenderungan umum yang mencari penyebab tunggal dan tidak memberi perhatian yang cukup pada penyebab-penyebab lain. Kebijakan untuk menyelesaikan masalah deforestasi yang tidak perlu dan tidak tepat, yang hanya terfokus pada satu bentuk pelaku pasti akan gagal mencapai sasarannya, karena kurang menghayati rumitnya masalah.

Kedua, penelitian di masa depan harus melanjutkan kecenderungan yang dimulai setelah tahun 1990 (lihat Tabel 1), dengan tidak membatasi diri pada pelaku pembukaan tutupan hutan (transmigran, perambah hutan, pemegang HPH, dll) saja. Agar penyebab langsung dan penyebab yang mendasari perubahan tataguna lahan dapat dipahami secara memadai, perlu dianalisa kecenderungan dan arah situasi politik, ekonomi dan sosial yang lebih luas pada tingkat lokal, regional, nasional dan internasional yang mempengaruhi perilaku di pinggiran hutan (forest margin).

\section{UCAPAN TERIMA KASIH}

Kedua penulis ingin menyampaikan ucapan terima kasih kepada mereka yang telah bermurah hati menyediakan waktu untuk memberi komentar pada konsep makalah ini: Arild Angelsen, Chris Bennet, Neil Byron, Dudung Darusman, Chris Elliott, Erwidodo, David Kaimowitz, Plinio Sist, Titus Sarijanto dan Jeff Sayer. Penulis bertanggung jawab atas kesalahan fakta atau intrepretasi yang mungkin masih ada dalam hasil akhir tulisan ini. 


\section{DAFTAR PUSTAKA}

Ahmad, M. 1995. The Role of Timber Production in Indonesian Economy: Reality or Illusion? Konphalindo, Jakarta.

Angelsen, A. 1995. Shifting cultivation and "deforestation": a study from Indonesia. World Development 23(10):17131729.

Ascher, W. 1993. Political economy and problematic forestry policies in Indonesia: obstacles to incorporating sound economics and science. The Center for Tropical Conservation, Duke University. July.

BAPPEDA dan PPKD. 1995. Profil Ladang Berpindah di Kalimantan Tengah. BAPPEDA Propinsi Dati I Kalimantan Tengah dan Pusat Penelitian Kebudayaan Dayak.

Barbier E.B., N. Bockstael, J.C. Burgess and I. Strand. 1993. The timber trade and tropical deforestation in Indonesia. LEEC Paper DP 93-01. London Environmental Economics Centre.

Barlow, C. and Muharminto. 1982. The rubber smallholder economy. Bulletin of Indonesian Economic Studies 18(2): 86-119.

Barlow, C. and T. Tomich. 1991. Indonesian agricultural development: the awkward case of smallholder tree crops. Bulletin of Indonesian Economic Studies 27 (3):29-53

Belcher, M. and A. Gennino. 1993. Southeast Asian Rainforests: A Resource Guide and Directory. Rainforest Action Network, San Francisco.

Chomitz, K.M. and C. Griffiths. 1996. Deforestation, shifting cultivation and tree crops in Indonesia: nationwide patterns of smallholder agriculture at the forest frontier. Research Project on Social and Environmental Consequences of Growth-Oriented Policies. Working Paper No. 4. The World Bank, Washington, DC.

Colfer, C.J. Pierce with R.G. Dudley. 1993. Shifting Cultivators of Indonesia: Marauders or Managers of the Forest? Community Forestry Case Study Series 6. Food and Agriculture Organization of the United Nations, Rome.

Dauvergne, P. 1994. The politics of deforestation in Indonesia. Pacific Affairs 66(4):497-518.

DepHut. 1995. Laporan: Inventarisasi dan Identifikasi Perladangan Berpindah/Perambahan Hutan Propinsi Kalimantan Timur, Tahun Anggaran 1994/1995. Departemen Kehutanan, Kantor Wilayah Propinsi Kalimantan Timur, Samarinda.

DepTrans. 1995. Kontribusi Pembangunan Transmigrasi Pelita V. Pusat Data dan Informasi. Sekretariat Jenderal Departemen Transmigrasi dan Pemukiman Perambah Hutan, Republik Indonesia, Jakarta.

DepTrans dan YDWL. 1996. Upaya Penanganan Permasalahan Perambah Hutan di Propinsi Kalimantan Timur (Taman Nasional Kutai) dan Kalimantan Selatan (Sungai Pinang). Departemen Transmigrasi dan Pemukiman Perambah Hutan, Kantor Wilayah Propinsi Kalimantan Timur dan Yayasan Dharma Wana Lestari, Fakultas Kehutanan, Universitas Mulawarman, Samarinda.

Dick, J. 1991. Forest land use, forest use zonation, and deforestation in Indonesia: a summary and interpretation of existing information. Background paper to UNCED for the State Ministry for Population and Environment (KLH) and the Environmental Impact Management Agency (BAPEDAL).

DJP. 1995. Statistik Perkebunan Indonesia 1994-1996. Direktorat Jendral Perkebunan, Jakarta.

Dove, M.R. 1993. Smallholder rubber and swidden agriculture in Borneo: a sustainable adaptation to the ecology and economy of the tropical forest. Economic Botany 47(2):136-147.

Dove, M.R. 1996. So far from power, so near to the forest: a structural analysis of gain and blame in tropical forest development. In C. Padoch and N.L. Peluso (eds), Borneo in Transition: People, Forests, Conservation, and Development. Oxford University Press, Kuala Lumpur. pp. 41-58.

Downton, M.W. 1995. Measuring tropical deforestation: development of the methods. Environmental Conservation 22(3):229-240.

D’Silva, E. and S. Appanah. 1993. Forestry Management for Sustainable Development. EDI Policy Seminar Report No. 32. The World Bank, Washington DC.

Durand, F. 1994. Les Forêts en Asie du Sud-Est: Recul et Exploitation. Le Cas de l'Indonésie. L'Harmattan, Paris.

Economist Intelligence Unit. 1995a. Country Profile: Indonesia 1994-95. The Economist Intelligence Unit, London.

Economist Intelligence Unit. 1995b. Country Report: Indonesia 4th Quarter 1995. The Economist Intelligence Unit, London.

Endogeotec Visicon. 1996. Studi pola migrasi perambah hutan. Lokasi: Sumatra Selatan dan Lampung. Endogeotec Visicon, Jakarta.

FAO. 1990. Situation and Outlook of the Forestry Sector in Indonesia. Volume 1: issues, findings and opportunities. Ministry of Forestry, Government of Indonesia; Food and Agriculture Organization of the United Nations, Jakarta. 
FAO. 1996. Forest Resources Assessment 1990: Survey of Tropical Forest Cover and Study of Change Processes. FAO Forestry Paper 130. Food and Agriculture Organization of the United Nations, Rome.

Fasbender, K.and S. Erbe. 1990. Towards a New Home: Indonesia's Managed Mass Migration. Verlag Weltarchiv GMBH, Hamburg.

Flint, E.P. 1994. Changes in land use in South and Southeast Asia from 1880 to 1980: a data base prepared as part of a coordinated research program on carbon fluxes in the tropics. Chemosphere 29(5):1015-1062.

Fraser, A.I. 1996. Social, economic and political aspects of forest clearance and land-use planning in Indonesia. Unpublished manuscript.

Gillis, M. 1988. The logging industry in tropical Asia. In J.S. Denslow and C. Padoch (eds), People of the Tropical Rainforest. University of California Press in association with Smithsonian Institution Traveling Exhibition Service, Berkeley. pp. 177-184.

GOI/FAO. 1996. National Forest Inventory of Indonesia: Final Forest Resources Statistics Report. Directorate General of Forest Inventory and Land Use Planning, Ministry of Forestry, Government of Indonesia and Food and Agriculture Organization of the United Nations, Jakarta.

Grainger, A. 1993. Controlling Tropical Deforestation. Earthscan, London.

Gray, J. and Soetrisno Hadi. 1990. Fiscal policies in Indonesian forestry. Directorate General of Forest Utilization, Ministry of Forestry, Government of Indonesia and Food and Agriculture Organization of the United Nations, Jakarta. April.

Hariadi. 1993. Rendahnya kontribusi pengusahaan hutan terhadap pembangunan regional. (The low level of economic contribution of forest enterprises to the regional development.) Teknolog 6(2):29-33.

Hasanuddin, L. 1996. Mitos-mitos pengelolaan hutan di Indonesia. Kertas Posisi No. 02. Wahana Lingkungan Hidup Indonesia / Friends of the Earth Indonesia.

Hill, H. 1994. Indonesia's New Order: The Dynamics of Socio-economic Transformation. Allen \& Unwin, St Leonards, NSW, Australia.

Holden, S. and H. Hvoslef. 1995. Transmigration settlements in Seberida: causes and consequences of the deterioration of farming systems of settlers in a rain forest environment. In O. Sandbukt (ed.), Management of Tropical Forests: Towards an Integrated Perspective. Centre for Development and the Environment, University of Oslo. pp. 107-125.

Holden, S., H. Hvoslef and R. Simanjuntak. 1995. Transmigration settlements in Seberida, Sumatra: deterioration of farming systems in a rain forest environment. Agricultural Systems 49(3):237-258.

Jepma, C.J. and M. Blom. 1992. Global trends in tropical forest degradation: the Indonesian case. WageningseEconomische-Studies 24:185-214

Kartawinata, K., T.C. Jessup and A.P. Vayda. 1989. Exploitation in Southeast Asia. In H. Lieth and M.J.A. Werger (eds), Tropical Rain Forest Ecosystems. Elsevier Science Publishers, Amsterdam. pp. 591-610.

Kartodihardjo, H. 1995. Kegagalan teori rente ekonomi hutan. Prisma (2):43-60.

King, D.Y. 1996. The political economy of forest sector reform in Indonesia. The Journal of Environment \& Development 5(2):216-232.

Kummer, D.L. and B.L. Turner II. 1994. The human causes of deforestation in Southeast Asia. BioScience 44(5):323-328.

Larson, D.F. 1996. A review of the palm oil subsector in Indonesia. International Economics Department, Commodity Policy and Analysis Unit, The World Bank, Washington, DC.

McBeth, J. 1995. Swamp for sale. Far Eastern Economic Review. September 7. pp. 58-59.

McClellan, S. 1992. Troubles of transmigration. Ceres 24(135):38-41.

MOF. 1992. Indonesia Tropical Forestry Action Program. Ministry of Forestry, Republic of Indonesia, Jakarta.

MOF. 1995. Country Brief: Indonesia Forestry Action Programme (IFAP). Ministry of Forestry, Republic of Indonesia, Jakarta.

Myers, N. 1995. The world's forests: need for a policy appraisal. Science 268:823-824.

Nancy, C. Pengaruh kebijaksanaan devaluasi terhadap ekspor karet alam Indonesia. (The influence of the devaluation policy on Indonesian rubber exports.) Bulletin Perkebunan Rakyat 4(2):35-38.

Osgood, D. 1994. Government failure and deforestation in Indonesia. In K. Brown and D.W. Pearce (eds), The Causes of Tropical Deforestation: the Economic and Statistical Analysis of Factors giving rise to the Loss of Tropical Forests. UCL Press, London. pp. 217-225.

PDP. 1996. Statistik Pertanian 1994. Pusat Data Pertanian, Departemen Pertanian, Jakarta.

Porter, G. 1994. The environmental hazards of Asia Pacific development: the Southeast Asian rainforests. Current History 93(587):430-434. 
Potter, L. 1993. The onslaught on the forests in South-East Asia. In H. Brookfield and Y. Byron (eds), South-East Asia's Environmental Future: The Search for Sustainability. United Nations University Press, Tokyo and Oxford University Press, Kuala Lumpur. pp. 103-123.

Potter, L. 1996. Forest degradation, deforestation, and reforestation in Kalimantan: towards a sustainable land use? In C. Padoch and N.L. Peluso (eds), Borneo in Transition: People, Forests, Conservation, and Development. Oxford University Press, Kuala Lumpur. pp. 13-40.

Ramli, R. and M. Ahmad. 1993. Rente Ekonomi Pengusahaan Hutan Indonesia. Wahana Lingkunan Hidup Indonesia, Jakarta.

RePPProT. 1990. The Land Resources of Indonesia: A National Overview. Regional Physical Planning Programme for Transmigration (RePPProT). Overseas Development Administration, London and Department of Transmigration, Jakarta.

RI. 1994. Rencana Pembangunan Lima Tahun Keenam 1994/95-1998/99. Buku III. Republik Indonesia, Jakarta.

Ross, M. 1996. Conditionality and logging reform in the tropics. In R.O. Keohane and M.A. Levy (eds), Institutions for Environmental Aid: Problems and Prospects. MIT Press, Cambridge, Massachusetts. pp 167-197

Saharjo, B.H. 1994. Deforestation with reference to Indonesia. Wallaceana 73:7-12.

Sayer, J.A. and T.C. Whitmore. 1991. Tropical moist forests: destruction and species extinction. Biological Conservation 55:199-213.

Secrett, C. 1986. The environmental impact of transmigration. The Ecologist 16(2/3):77-88.

Siebert, S.F., J.M. Belsky and K. Rauf. 1994. Rattan management for sustainable livelihoods and forest conservation: the case of Kerinci-Seblat National Park, Indonesia. In M. Munasinghe and J. McNeely (eds), Protected Area Economics and Policy: linking conservation and sustainable development. World Bank, Washington, DC. pp 125-132.

Soemarwoto, O. 1992. Peranan hutan tropik dalam hidro-orologi, pemanasan global dan keanekaan hayati. Dalam Mochtar Lubis (penyunting) Melestarikan Hutan Tropika: Permasalahan, manfaat dan kebijakannya. Yayasan Obor Indonesia, Jakarta. pp. 1-26.

Sutter, Harald. 1989. Forest Resources and Land Use in Indonesia. Indonesia Forestry Studies, Field Document No. I1. Ministry of Forestry, Government of Indonesia and Food and Agriculture Organization of the United Nations, Jakarta.

TAG (Transmigration Advisory Group). 1991. Forest Clearance Study. Ministry of Transmigration, Jakarta.

Thiele, R. 1994. How to manage tropical forests more sustainably: the case of Indonesia. Intereconomics 29(4):184-193.

Theile, R. 1995. Conserving tropical rain forests in Indonesia: a quantitative assessment of alternative policies. Journal of Agricultural Economics 46(2):187-200.

Tomich, T.P. and M. van Noordwijk. 1995. What drives deforestation in Sumatra? Paper presented at Regional Symposium on "Montane Mainland Southeast Asia in Transition", Chiang Mai, Thailand, 13-16 November.

UNESC. 1996. Programme Element I.2: Underlying causes of deforestation and forest degradation. Report of the Secretary General. E/CN.17/IPF 1996/2. 13 Feb. 1996. United Nations Economic and Social Council, New York.

WALHI. 1992. Violated Trust: Disregard for the Forests and Forest Laws of Indonesia. The Indonesian Environmental Forum (WALHI), Jakarta.

WALHI/YLBHI. 1992. Mistaking Plantations for Indonesia's Tropical Forests. Wahana Lingkungan Hidup; Yayasan Lembaga Bantuan Hukum Indonesia, Jakarta.

Weinstock, J.A. and Satyawan Sunito. 1989. Review of shifting cultivation in Indonesia. Directorate General of Forest Utilization, Ministry of Forestry, Government of Indonesia and Food and Agriculture Organization of the United Nations, Jakarta.

Whitten, A.J. 1987. Indonesia's transmigration program and its role in the loss of tropical rain forests. Conservation Biology 1(3):239-246.

World Bank. 1988. Indonesia: The Transmigration Program in Perspective. The World Bank, Washington, DC.

World Bank. 1990. Indonesia: Sustainable Development of Forests, Land, and Water. The World Bank, Washington, DC.

World Bank. 1994. Indonesia: Environment and Development. The World Bank, Washington, DC.

World Bank. 1995. The economics of long term management of Indonesia's natural forest. Unpublished manuscript. August.

World Bank. 1996. Indonesia: Dimensions of Growth. Report No. 15383-IND. Country Department III, East Asia and Pacific Region. The World Bank, Washington, DC.

Zerner, C. 1992. Indigenous forest-dwelling communities in Indonesia's outer islands: livelihood, rights, and environmental management institutions in the era of industrial forest exploitation. Unpublished manuscript. 